\title{
Borane B-C Bond Cleavage by a Low-Coordinate Iron Hydride Complex and N-N Bond Cleavage by the Hydridoborate Product
}

\author{
Ying Yu, William W. Brennessel, and Patrick L. Holland \\ Department of Chemistry, University of Rochester, NY 14627
}

\begin{abstract}
The iron(II) hydride dimers $\left[\mathrm{L}^{\mathrm{R}} \mathrm{Fe}(\mu-\mathrm{H})_{2} \mathrm{FeL}^{\mathrm{R}}\right]$ ( $\mathrm{L}^{\mathrm{Me}}=2$,4-bis(2,6-diisopropylphenylimino) pent-3$\mathrm{yl} ; \mathrm{L}^{\mathrm{tBu}}=2,2,6,6$-tetramethyl-3,5-bis(2,6-diisopropylphenylimino)hept-4-yl) abstract hydrocarbyl groups from $\mathrm{BR}_{3}{ }_{3}\left(\mathrm{R}^{\prime}=\mathrm{Et}, \mathrm{Ph}\right)$ to give $\mathrm{L}^{\mathrm{R}} \mathrm{FeR}^{\prime}$ and $\mathrm{L}^{\mathrm{R}} \mathrm{Fe}(\mu-\mathrm{H})_{2} \mathrm{BR}_{2}{ }_{2}$. Mechanistic studies with $\mathrm{R}=$ $\mathrm{R}^{\prime}=\mathrm{Me}$ are consistent with a process in which the hyride dimer opens one $\mathrm{Fe}-\mathrm{H}$ bond, and subsequent $\mathrm{B}-\mathrm{H}$ bond formation is concerted with dissociation of an Fe-H unit. Cleavage of boron-carbon bonds is likely to proceed at least in part from transient quaternary borate anions. In a separate bond-breaking reaction, $\mathrm{L}^{\mathrm{Me}} \mathrm{Fe}(\mu-\mathrm{H})_{2} \mathrm{BEt}_{2}$ reacts with $\mathrm{N}_{2} \mathrm{H}_{4}$ to eject $\mathrm{H}_{2}$ from the bridging hydrides and cleave the $\mathrm{N}-\mathrm{N}$ bond in the diaminoborate complex $\mathrm{L}^{\mathrm{Me}} \mathrm{Fe}\left(\mu-\mathrm{NH}_{2}\right)_{2} \mathrm{BEt}_{2}$. These novel bond-breaking reactions are facilitated by the low coordination number at the iron(II) center.
\end{abstract}

\section{Keywords}

Iron(II); B-C bonds; borane; N-N bonds; mechanism

\section{Introduction}

In addition to their classic roles as intermediates in homogeneous catalytic reactions of organometallic complexes, ${ }^{1}$ iron hydrides have been postulated to be reactive intermediates in the mechanisms of hydrogenase ${ }^{2}$ and nitrogenase ${ }^{3}$ enzymes. We have become especially interested in exploring the chemistry of unsaturated hydride complexes of the late transition metals because of the juxtaposition of the reactive $\mathrm{M}-\mathrm{H}$ functionality and an open coordination site for substrate binding.

We have used bulky $\beta$-diketiminate ligands (Figure 1) to enable the synthesis of the only known three-and four-coordinate iron hydride complexes. ${ }^{4,5}$ These unsaturated iron hydrides, $\mathrm{L}^{\mathrm{R}} \mathrm{Fe}$ $(\mu-\mathrm{H})_{2} \mathrm{FeL}^{\mathrm{R}}$, are prepared from reactions between iron(II) chloride complexes and potassium triethylborohydride (eq 1a and 1b).

$$
\begin{aligned}
{\left[\mathrm{L}^{\mathrm{Me}} \mathrm{FeCl}\right]_{2}+2 \mathrm{KHBEt}_{3} } & \rightarrow \mathrm{L}^{\mathrm{Me}} \mathrm{Fe}(\mu-\mathrm{H})_{2} \mathrm{FeL}^{\mathrm{Me}}(\mathbf{1 a})+2 \mathrm{BEt}_{3}+2 \mathrm{KCl} \\
\mathrm{L}^{\mathrm{tBu}} \mathrm{FeCl}+2 \mathrm{KHBEt}_{3} & \rightarrow 0.5 \mathrm{~L}^{\mathrm{tBu}} \mathrm{Fe}\left(\mu-\mathrm{H}_{2} \mathrm{FeL}^{\mathrm{BBu}}(\mathbf{1} \mathbf{b})+\mathrm{BEt}_{3}+\mathrm{KCl}\right.
\end{aligned}
$$

Although both iron hydride compounds exist as dimers in the solid state, they behave differently in solution: $\mathrm{L}^{\mathrm{tBu}} \mathrm{Fe}(\mu-\mathrm{H})_{2} \mathrm{FeL}^{\mathrm{tBu}}$ dissociates into monomers in solution, ${ }^{4 \mathrm{a}}$ while only dimer is observed in solutions of the $\mathrm{L}^{\mathrm{Me}} \mathrm{Fe}(\mu-\mathrm{H})_{2} \mathrm{FeL}^{\mathrm{Me} .4 \mathrm{~b}}$ One phenomenon caught our attention during the preparation of the iron hydride complexes: long reaction time (>30 $\mathrm{min}$ at room 
temperature) or heating leads to the formation of red products instead of the brown iron hydride complexes. Here, we report that the iron hydride complex reacts with the byproduct $\mathrm{BEt}_{3}$ to give an iron dihydridoborate complex and an iron ethyl complex (Scheme 1).

The reaction in Scheme 1 features migration of a boron-bound hydrocarbyl group. Boron-tocarbon migrations have precedent in the organic chemistry literature, where alkylboranes have been utilized for forming $\mathrm{N}-\mathrm{C}$ or $\mathrm{C}-\mathrm{C}$ bonds to nucleophiles that contain a potential leaving group (e.g. deprotonated $\alpha$-haloesters or carbon monoxide). ${ }^{6}$ In these reactions, trialkylborane initially attacks the nucleophile to form a quaternary adduct, and one of the boron $\mathrm{R}$ groups subsequently migrates to the adjacent $\mathrm{N}$ or $\mathrm{C}$, displacing a leaving group. The migration of hydrocarbyl groups from boron to a transition metal is also a key step of the Suzuki-Miyaura reaction, the transmetallation of the organoboron compound to form organopalladium species (Scheme 2). ${ }^{7}$ Interestingly, in both organic and organometallic precedents, quaternary anionic boron species are the actual alkyl/aryl group donor. For example, transmetallation from boron to palladium in the Sukuzi-Miyaura reaction is typically promoted by adding bases to form a quaternary borate anion (Scheme 2, bottom). ${ }^{6 a}, 8,9$ Since the B-C bond cleavage in Scheme 1 requires no added base, and occurs in non-coordinating solvents, we were curious to learn whether this reaction is mechanistically distinct from the palladium reaction, possibly leading to insights on strategies for milder cross-coupling reactions.

Few boron alkylations of any sort are understood in great mechanistic detail. ${ }^{10}$ Below, we describe kinetic studies that give insight into the mechanism of this transformation. The hydridoborate product also undergoes an interesting reaction with hydrazine to cleave the N$\mathrm{N}$ bond to yield a diaminoborate complex.

\section{Results and Discussion}

\section{Formation of the dihydridoborate complex from $L^{R} \mathrm{Fe}(\mu-\mathrm{H})_{2} \mathrm{FeL}^{\mathrm{R}}$ and $\mathrm{BEt}_{3}$}

Reaction of the iron hydride dimers $\mathrm{L}^{\mathrm{R}} \mathrm{Fe}(\mu-\mathrm{H})_{2} \mathrm{FeL}^{\mathrm{R}}\left(\mathrm{L}^{\mathrm{R}}=\beta\right.$-diketiminate ligands shown in Figure 1; $\mathbf{1 a}$ with $\mathrm{R}=\mathrm{Me}$ and $\mathbf{1 b}$ with $\mathrm{R}=\mathrm{tBu})$ with one molar equivalent of $\mathrm{BR}_{3}(\mathrm{R}=\mathrm{Et}, \mathrm{Ph})$ in toluene at $80^{\circ} \mathrm{C}$ for $22 \mathrm{~h}$ leads to an equimolar mixture of a four-coordinate hydridoborate complex, $\mathrm{L}^{\mathrm{R}} \mathrm{Fe}(\mu-\mathrm{H})_{2} \mathrm{BR}_{2}{ }_{2}\left(\mathrm{R}=\mathrm{Me}, \mathrm{R}^{\prime}=\mathrm{Et} \mathbf{2 a}\right.$ or $\left.\mathrm{Ph} \mathbf{2 b} ; \mathrm{R}={ }^{\mathrm{t}} \mathrm{Bu}, \mathrm{R}^{\prime}=\mathrm{Et} \mathbf{2 c}\right)$, and an iron alkyl complex $\mathrm{L}^{\mathrm{R}} \mathrm{FeR} \mathrm{R}^{\prime}\left(\mathrm{R}=\mathrm{Me}, \mathrm{R}^{\prime}=\mathrm{Et} \mathbf{3} \mathbf{a}\right.$ or $\left.\mathrm{Ph} \mathbf{3 b} ; \mathrm{R}={ }^{\mathrm{t}} \mathrm{Bu}, \mathrm{R}^{\prime}=\mathrm{Et} \mathbf{3 c}\right) .{ }^{11}$ These reactions are shown in Scheme 3. Reaction of $\mathbf{1 a}$ with $\mathrm{B}(\mathrm{OEt})_{3}$ and $\mathrm{B}(\mathrm{iBu})_{3}$ gave multiple unidentified products, and these reactions were not pursued further.

The alkyliron compounds $\mathbf{3 a}$ and $\mathbf{3 c}$ were identified by comparison to their known ${ }^{1} \mathrm{H}$ NMR spectra (they can be prepared independently from $\left[\mathrm{L}^{\mathrm{R}} \mathrm{FeCl}\right]_{\mathrm{n}}(\mathrm{n}=1$ or 2$)$ and Grignard reagents). ${ }^{12}$ The new complex $\mathrm{L}^{\mathrm{Me}} \mathrm{FePh}(\mathbf{3 b})$ was previously unknown, and so it was generated from the reaction of $\left[\mathrm{L}^{\mathrm{Me}} \mathrm{Fe}(\mu-\mathrm{Cl})_{2} \mathrm{FeL}^{\mathrm{Me}}\right]$ with $\mathrm{PhMgCl}$. Its spectroscopic features and X-ray crystal structure (see Experimental Section for spectroscopy and Supporting Information for solid-state structure) are analogous to those for the three-coordinate alkyl complexes. The ${ }^{1} \mathrm{H}$ NMR spectrum of independently prepared $\mathbf{3 b}$ verifies that it is identical to one of the products from reaction of $\mathrm{L}^{\mathrm{Me}} \mathrm{Fe}(\mu-\mathrm{Cl}) \mathrm{FeL}^{\mathrm{Me}}$ and $\mathrm{BPh}_{3}$.

The new (dihydridoborate)iron(II) complexes $\mathbf{2 a}, \mathbf{2 b}$, and $\mathbf{2 c}$ were isolated in $59-72 \%$ yield after fractional crystallization away from the iron(II) alkyl/aryl complexes. The reaction of 1a with $\mathrm{BEt}_{3}$ was very clean: 1a, 2a, and 3a are the only compounds observed in ${ }^{1} \mathrm{H}$ NMR spectra of the reaction mixture. In the other reactions, there were a few unidentified paramagnetic peaks in the crude mixtures, representing side products that were removed by crystallization. Each dihydridoborate complex exhibits a magnetic moment of 4.0(1) to 5.7(1) $\mu_{\mathrm{B}}$ in $\mathrm{C}_{6} \mathrm{D}_{6}$ solution, indicating a high-spin iron(II) center $(S=2)$. Each ${ }^{1} \mathrm{H}$ NMR spectrum covers an extremely wide range from $100 \mathrm{ppm}$ to $-310 \mathrm{ppm}$, with large chemical shift 
dispersion as a result of the paramagnetic iron ion. The proton resonances were generally assigned from the relative integrations (see Experimental Section). The six-proton peaks for the $\mathrm{BEt}_{2}$ group and the $\mathrm{L}^{\mathrm{Me}}$ backbone could be distinguished because the ${ }^{1} \mathrm{H}$ NMR spectra of $\mathrm{L}^{\mathrm{Me}} \mathrm{Fe}(\mu-\mathrm{H})_{2} \mathrm{BEt}_{2}$ and $\mathrm{L}^{\mathrm{tBu}} \mathrm{Fe}(\mu-\mathrm{H})_{2} \mathrm{BEt}_{2}$ differ only by the 6-proton resonance in the $\mathrm{L}^{\mathrm{Me}}$ compound and the 18 -proton resonance in the $\mathrm{L}^{\mathrm{tBu}}$ compound. The bridging hydride protons are not observed because of fast relaxation.

A single crystal of each iron dihydridoborate complex was grown from pentane. The solidstate structure of 2a is shown in Figure 2 as an example, and others may be found in the Supporting Information. The bridging hydride ions were located and refined with an isotropic thermal parameter in each structure (the two hydrides are crystallographically distinct, except in the case of $\mathrm{L}^{\mathrm{Me}} \mathrm{Fe}(\mu-\mathrm{H})_{2} \mathrm{BEt}_{2}$, where the hydride positions are related by a $C_{2}$ axis). Including the two $\mathrm{Fe}-\mathrm{H}$ bonds, each iron center has a pseudotetrahedral geometry with a $\mathrm{Fe}-\mathrm{H}$ distance of about $1.7 \AA$ (Table 1). Although the Fe' B distances are relatively short (ca. $2.24 \AA$ ), we do not postulate any direct $\mathrm{Fe}-\mathrm{B}$ bonding interaction because the two atoms are held in proximity by the bridging hydride. ${ }^{13}$ The B-H distances range from 1.19(2) $\AA$ to $1.35(2) \AA$, which is comparable to the average M-H-B distance of $1.24 \AA$ in the Cambridge Structural Database.

The formation of $\mathbf{2}$ and $\mathbf{3}$ is the result of an interesting B-C bond cleavage. Previous examples of B-C cleavage are most often from nucleophilic borates, rather than from boranes. ${ }^{14}$ In complexes with covalently bound hydridoborate ligands, $\mathrm{BH}_{\mathrm{n}} \mathrm{R}_{4-\mathrm{n}}{ }^{-}(\mathrm{n}=1-4, \mathrm{R}=\mathrm{H}$ or alkyl $)$ complexes are much less common than borohydride $\left(\mathrm{BH}_{4}{ }^{-}\right)$complexes. ${ }^{15}$ Known examples of $\mathrm{MH}_{2} \mathrm{BR}_{2}$ complexes typically come from double metathesis reactions of a metal chloride complex with an alkali metal salt of $\mathrm{H}_{2} \mathrm{BR}_{2}\left(\mathrm{R}_{2}=\mathrm{H}_{2}, 16 \mathrm{C}_{5} \mathrm{H}_{10}, \mathrm{C}_{8} \mathrm{H}_{14}{ }^{17}\right.$ and $\left.\mathrm{Et}_{2}{ }_{2}^{15 b}, 18\right)$. In some literature cases, the $\mathrm{H}_{2} \mathrm{BEt}_{2}{ }^{-}$group was present from impurities in commercial $\mathrm{HBEt}_{3}{ }^{-} .15 \mathrm{~b},{ }^{1819}$ Here, the hydridoborate product is formed from cleavage of the B-C bond of a trialkylborane, and not from a dihydridoborate impurity in the starting material (see below).

\section{Reaction of $\mathrm{L}^{\mathrm{Me}} \mathrm{Fe}(\mu-\mathrm{H})_{2} \mathrm{FeL}^{\mathrm{Me}}$ with $\mathrm{BR}_{3}$ : Rate Law and Activation Parameters}

We used the reaction of $\mathrm{L}^{\mathrm{Me}} \mathrm{Fe}(\mu-\mathrm{H})_{2} \mathrm{FeL}^{\mathrm{Me}}(\mathbf{1 a})$ with $\mathrm{BEt}_{3}$ as the subject of kinetic studies because of the simple ${ }^{1} \mathrm{H}$ NMR spectra of the starting material and the exceptionally clean reaction. Using an internal integration standard $\left(\mathrm{L}^{\mathrm{tBu}} \mathrm{FeCl}\right)$ in a sealed capillary, we verified that the spectroscopic yields of products are $95 \%$ and $99 \%$ for $\mathrm{L}^{\mathrm{Me}} \mathrm{Fe}(\mu-\mathrm{H})_{2} \mathrm{BEt}_{2}(\mathbf{2 a})$ and $\mathrm{L}^{\mathrm{Me}} \mathrm{FeEt}(\mathbf{3 a})$ respectively. In the kinetics experiments, various amounts of $\mathbf{1 a}$ and $\mathrm{BEt}_{3}(>10$ equiv relative to 1a) were mixed in $\mathrm{C}_{6} \mathrm{D}_{6}$ and held at various temperatures between $6.5^{\circ} \mathrm{C}$ and $59.7{ }^{\circ} \mathrm{C}$. Complexes $\mathbf{2 a}$ and $\mathbf{3 a}$ were the only products observed by ${ }^{1} \mathrm{H}$ NMR spectroscopy. The integrations of the peaks at 13 ppm (1a), 17 ppm (2a), and -11 ppm (3a) were followed as a function of time, and invariably showed exponential decays. The rate constant was independent of $[\mathrm{Fe}]$ when a drop of liquid mercury was added to the reaction mixtures. Without the mercury, we observed a slight decrease in $k_{\mathrm{obs}}$ from $3.97(7) \times 10^{-3} \mathrm{~s}^{-1}$ to $2.51(2) \times 10^{-3}$ $\mathrm{s}^{-1}$ with an increase of [1a] from $11.1 \mathrm{mM}$ to $42.3 \mathrm{mM}$. With added $\mathrm{Hg}^{0}$, the derived $k_{\text {obs }}$ showed no clear trend while changing [1a] from $20 \mathrm{mM}$ to $40 \mathrm{mM}$. Therefore, subsequent trials were run with a drop of mercury, which presumably amalgamates trace metallic iron.

For consistency, the following use exclusively the rate constants derived from following the decrease of 1a (Table 2). The rate has a first-order dependence on [1a] (as evident from its exponential decay, and the constancy of the rate constant upon variation of [1a]) and a firstorder dependence on $\left[\mathrm{BEt}_{3}\right]$ (from the linear dependence of the pseudo-first-order rate constant on $\mathrm{BEt}_{3}$ concentration). Therefore, the rate law is

$$
\text { rate }=-d[\mathbf{1 a}] / d t=k[\mathbf{1} \mathbf{a}]\left[\mathrm{BEt}_{3}\right]
$$


The second-order rate constant at room temperature $\left(21.5^{\circ} \mathrm{C}\right)$ was $4.9(1) \times 10^{-4} \mathrm{M}^{-1} \mathrm{~s}^{-1}$. Activation parameters were calculated from an Eyring plot of second-order rate constants from $6.5^{\circ} \mathrm{C}$ to $59.7{ }^{\circ} \mathrm{C}$, giving $\Delta \mathrm{H}^{\ddagger}=21.8 \pm 0.8 \mathrm{kcal} \cdot \mathrm{mol}^{-1}$ and $\Delta \mathrm{S}^{\ddagger}=-1 \pm 2$ eu. ${ }^{20}$

Table 4 shows that varying the steric demands of the diketiminate ligand and $\mathrm{BR}_{3}$ gives rate constants of the same magnitude, which slightly increase with a larger borane $\left(\mathrm{BPh}_{3}\right)$ or diketiminate ligand $\left(\mathrm{L}^{\mathrm{tBu}}\right)$. Therefore, there is only a small steric influence on the reaction rate.

Finally, the reaction of $\mathbf{1 a}$ with $\mathrm{BEt}_{3}$ was repeated in different polar solvents $(75 \% o$ difluorobenzene $/ 25 \% \mathrm{C}_{6} \mathrm{D}_{6}$ or THF- $d_{8}$ ). We observed a small increase in rate constant using THF, but no increase in a more polar mixture of $o$-difluorobenzene and benzene (Table 5). The similarities in rate with a more polar solvent mixture suggests that charged species are not formed in the rate-limiting transition state (see below). The rate increase in THF may be from coordination to THF to intermediates, but the nature of this interaction was not queried further.

\section{B-C Bond Cleavage: Mechanistic Hypotheses}

Several reasonable mechanisms can be proposed for the B-C bond cleavage reaction. We do not consider mechanisms in which $\mathrm{BR}_{3}$ undergoes $\beta$-hydride elimination because the reaction is equally facile with $\mathrm{BPh}_{3}$, for which $\beta$-hydride elimination is impossible. Moreover, independent experiments show that $\mathrm{BEt}_{3}$ and 1-hexene do not react when heated for $2 \mathrm{~h}$ at 80 ${ }^{\circ} \mathrm{C}$, indicating that borane alkyl groups do not undergo substantial $\beta$-hydride elimination under the conditions of the reaction in Scheme 1.

The mechanisms considered here are grouped into categories: dissociation of the iron hydride dimer into monomers before reaction with borane $(\underline{\mathbf{A}})$, concerted Fe-H and B-C cleavage with B-H formation $(\underline{\mathbf{B}}, \underline{\mathbf{C}}, \underline{\mathbf{D}})$, and formation and disproportionation of a transient iron triethylborohydride species $(\underline{\mathbf{E}}, \underline{\mathbf{F}})$.

\section{Dissociation of 1a into monomer}

Mechanism $\underline{\mathbf{A}}$ (Scheme 4) illustrates the potentialdissociation of the iron hydridedimer as part of the mechanism. A mechanism of this type was strongly implicated in the reaction of $\mathrm{L}^{\mathrm{tBu}} \mathrm{Fe}(\mu-\mathrm{H})_{2} \mathrm{FeL}^{\mathrm{tBu}}$ with 3-hexyne, where a zero-order dependence on alkyne concentration indicated an intramolecular rate-limiting step prior to any interaction with alkyne. ${ }^{4}$ However, in the reaction with borane described here, hydride dissociation can be ruled out because it does not predict the observed rate law. Mechanism $\underline{\mathbf{A}}$ would lead to a zero-order dependence on [BEt 3 if $k_{1}$ (dimer dissociation) were rate-limiting, or a half order dependence on [1a] if $k_{2}$ (attack of borane) were rate-limiting.

$$
\text { A, } k_{1} \text { rate limiting: } \quad \text { rate }=k_{1}[\mathbf{1 a}]
$$

$$
\text { A, } k_{2} \text { rate limiting: } \quad \text { rate }=k_{2}[\mathrm{LFeH}]\left[\mathrm{BEt}_{3}\right]=k_{2} K_{\mathrm{eq}}{ }^{1 / 2}[\mathbf{1 a}]^{1 / 2}\left[\mathrm{BEt}_{3}\right] \text { where } K_{\mathrm{eq}}=k_{1} / k_{-1}
$$

The time course of the concentration of $\mathbf{1 a}$ is inconsistent with a half-order dependence of the rate on $[\mathbf{1 a}]$.

\section{Concerted mechanisms}

In mechanism $\underline{\mathbf{B}}, \mathbf{1 a}$ reacts with $\mathrm{BEt}_{3}$ in an initial rate-limiting step. While the empty boron $\mathrm{p}$ orbital interacts with the bridging hydride, the nucleophilic boron-bound alkyl group simultaneously approaches the iron atom of $\mathbf{1 a}$. This resembles the " $\sigma$-bond metathesis" mechanism that explains $\mathrm{C}-\mathrm{H}$ activation reactions by $\mathrm{d}^{0}$ metal centers. ${ }^{24}$ This pathway leads to the observed products after dissociation of a bridging hydride, and is the microscopic reverse 
of the reaction of a ruthenium alkyl complex with catecholborane through a $\sigma$-bond metathesis mechanism. 25

Mechanism $\underline{\mathbf{C}}$, on the other hand, begins with $\mathrm{Fe}-\mathrm{H}$ bond breaking. After dissociating one of the Fe-H bonds, the "open" isomer leads to a six-membered transition state for a pericyclic reaction. As long as the initial $\mathrm{Fe}-\mathrm{H}$ opening is rapid and reversible, mechanism $\underline{\mathbf{C}}$ agrees with the experimental rate law, rate $=k[\mathbf{1 a}]\left[\mathrm{BEt}_{3}\right]$.

Mechanism $\underline{\mathbf{D}}$ (Scheme 7) starts with rate-limiting abstraction of " $\mathrm{H}^{-}$" from $\mathbf{1 a}$ by the borane, breaking two of the $\mathrm{Fe}-\mathrm{H}$ bonds and forming free $\mathrm{HBEt}_{3}{ }^{-}$. Previous researchers have observed alkyl group transfers from a borate to a metal center, which is more common compared to group transfer from borane species. ${ }^{14}$ In analogy, mechanism $\underline{\mathbf{D}}$ concludes with transfer of an ethyl group from $\mathrm{HBEt}_{3}{ }^{-}$to iron. The ion pair undergoes a $\sigma$-bond metathesis to give the final

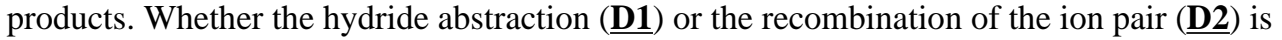
rate limiting, the predicted rate law is the same as mechanisms $\underline{\mathbf{B}}$ and $\underline{\mathbf{C}}$ : a first order dependence on both [1a] and $\left[\mathrm{BEt}_{3}\right]$, in concord with the observed rate law.

Notably, each of these mechanisms suffers from inconsistencies with other mechanistic data. First, the entropy of activation near zero is difficult to rationalize in the light of the bimolecular transition states in these mechanisms. In order to outweigh the expected large negative entropy change from bringing two molecules together, it is necessary to have a roughly equivalent release of entropy prior to the rate-limiting step. This situation is provided only by mechanisms $\underline{\mathbf{C}}$ and $\underline{\mathbf{D 2}}$, where the observed rate constant $k_{\mathrm{obs}}$ is actually a product of the equilibrium constant for cleavage one or two Fe-H bond(s) in $\mathbf{1 a}\left(\mathrm{K}_{\mathrm{FeH}}\right)$ and the rate constant for the elementary step consisting of the pericyclic reaction, $k_{\text {peri }}$; $k_{\mathrm{obs}}=\mathrm{K}_{\mathrm{FeH}} k_{\text {peri }}$. Therefore $\Delta \mathrm{S}_{\text {obs }}^{\ddagger}=\Delta \mathrm{S}_{\mathrm{FeH}}+$ $\Delta S^{\ddagger}$ peri. We cannot determine either of these individual entropy values quantitatively, but it is reasonable to postulate that the entropy increase from partly opening the crowded dimer structure of $\mathbf{1 a}\left(\Delta \mathrm{S}_{\mathrm{FeH}}\right)$ could roughly equal the entropy decrease of bringing in the borane or borate to reach the transition state for the pericyclic reaction $\left(\Delta \mathrm{S}^{\ddagger}\right.$ peri $)$. Molecular models of the reactants suggest that only an intermediate generated by cleavage of the $\mathrm{Fe}_{2} \mathrm{H}_{2}$ ring (as in mechanism $\underline{\mathbf{C}}$ and $\underline{\mathbf{D 2}}$ ) would have sufficient space for approach of the borane or borate B-C bond.

However, it is difficult to rationalize the similar observed reaction rate between $\mathrm{BEt}_{3}$ and $\mathrm{BPh}_{3}$ if mechanism $\underline{\mathbf{C}}$ is followed. In the six-membered ring transition state, one of the $\mathrm{R}$ groups from the borate sits between the $\mathrm{BR}_{2}$ fragment and the $\mathrm{L}^{\mathrm{Me}} \mathrm{Fe}$ fragment. Considering the huge hindrance from the $\beta$-diketiminate ligand, this conformation is expected to have different steric effects for ethyl and phenyl groups. This argument, as well as the near-zero entropy of activation, makes mechanism $\underline{\mathbf{C}}$ less plausible.

In mechanisms $\underline{\mathbf{D}}$, we note that an ionic intermediate is formed in or before the rate-limiting transition state. The rate of disappearance of 1a has very little dependence on solvent polarity, though polar solvents are expected to stabilize transition states in which charge is developing. Therefore, the solvent effect is inconsistent with mechanism $\underline{\mathbf{D}}$.

\section{Borohydride disproportionation mechanisms}

Commercial solutions of Super-Hydride $\left(\mathrm{LiHBEt}_{3}\right)$ have been reported to undergo disproportionation to $\mathrm{LiBEt}_{4}$ and $\mathrm{Li}\left[\mathrm{BH}_{2} \mathrm{Et}_{2}\right]$ at room temperature over long time periods (eq 3). $15 \mathrm{~b}, 18 \mathrm{~b}, 18 \mathrm{c}, 26$ The resulting $\mathrm{Li}\left[\mathrm{BH}_{2} \mathrm{Et}_{2}\right]$ can lead to $\mathrm{H}_{2} \mathrm{BEt}_{2}$ complexes by metathesis with a metal chloride. In addition, solutions of $\mathrm{LiHBEt}_{3}$. THF are known to react with $\mathrm{BEt}_{3}$ to give $\mathrm{LiBEt}_{4}$ and $\left(\mathrm{HBEt}_{2}\right)_{2}$, and subsequently $\mathrm{Li}\left[\mathrm{BH}_{2} \mathrm{Et}_{2}\right] 18 \mathrm{c}, 26$ (eq 3, 4).

$$
2 \mathrm{LiHBEt}_{3} \rightarrow \mathrm{Li}\left(\mathrm{H}_{2} \mathrm{BEt}_{2}\right)+\mathrm{LiBEt}_{4}
$$




$$
2 \mathrm{BEt}_{3}+2 \mathrm{LiHBEt}_{3} \rightarrow\left(\mathrm{HBEt}_{2}\right)_{2}+\mathrm{LiBEt}_{4}
$$

However, the spurious presence of diethylborohydride anions is not likely to be involved in the reaction of $\mathbf{1 a}$ with $\mathrm{BR}_{3}$ for the following reasons. First, our $\mathrm{KHBEt}_{3}$ was prepared inhouse from $\mathrm{KH}$ and $\mathrm{BEt}_{3}$ in toluene (eq 4) and stored as a solid. The ${ }^{11} \mathrm{~B}$ NMR spectrum of this isolated $\mathrm{KHBEt}_{3}$ in $\mathrm{C}_{6} \mathrm{D}_{6}$ has a single peak at $-16 \mathrm{ppm}$, with no signs of dihydridoborate or $\mathrm{BEt}_{3}$ impurities. The ${ }^{11} \mathrm{~B}$ NMR spectrum of $\mathrm{KHBEt}_{3}$ did not show any change when heated to $80^{\circ} \mathrm{C}$ for $2 \mathrm{~h}$ in benzene- $d_{6}$ (mimicking the conditions of our kinetic experiments). An even more convincing piece of evidence is our ability to synthesize $\mathrm{L}^{\mathrm{Me}} \mathrm{FeH}_{2} \mathrm{BEt}_{2}$ from $\mathbf{1 a}$ and $\mathrm{BEt}_{3}$, a reaction in which $\mathrm{KHBEt}_{3}$ is not present. Therefore, the presence of potassium diethylborohydride in our reaction is unlikely, and there is no necessity for hydridoborate salts in for the reaction to occur.

It is still necessary to consider the transient formation of trialkylborohydride species later in the pathway. For example, the first step of the reaction might resemble the reaction of alkali metal hydrides with triethylborane 27 (eq 5).

$$
\mathrm{KH}+\mathrm{BEt}_{3} \rightarrow \mathrm{KHBEt}_{3}
$$

The analogous reaction at iron would form a transient iron triethylborohydride complex, $\mathrm{L}^{\mathrm{Me}} \mathrm{Fe}\left(\mathrm{HBEt}_{3}\right.$ ), either through monomer (mechanism $\underline{\mathbf{E}}$ ) or through a partially open dimer (mechanism $\underline{\mathbf{F}}$ ). Because $\mathrm{L}^{\mathrm{Me}} \mathrm{Fe}\left(\mathrm{HBEt}_{3}\right)$ is the presumed intermediate in the reaction of $\mathrm{L}^{\mathrm{Me}} \mathrm{FeCl}$ and $\mathrm{KHBEt}_{3}$ to form $\mathrm{L}^{\mathrm{Me}} \mathrm{Fe}(\mu-\mathrm{H})_{2} \mathrm{FeL}^{\mathrm{Me}}+\mathrm{KCl}+\mathrm{BEt}_{3}$ (eq 1a, above), steps preceding the formation of this intermediate are assumed to be reversible (Scheme 8)

In Scheme 8, the transient iron triethylborohydride species lies in the center. Since $\mathrm{L}^{\mathrm{Me}} \mathrm{Fe}$ $\left(\mathrm{HBEt}_{3}\right)$ is not observed by NMR spectroscopy during any reaction, this intermediate must be consumed very quickly $\left(k_{\mathrm{d}}, k_{-2}\right.$ and $k_{-2}^{\prime}$ are large). Assuming that $\mathrm{L}^{\mathrm{Me}} \mathrm{Fe}\left(\mathrm{HBEt}_{3}\right)$ is an intermediate on the way to $\left[\mathrm{L}^{\mathrm{Me}} \mathrm{Fe}(\mu-\mathrm{H})_{2} \mathrm{FeL}^{\mathrm{Me}}\right]_{2}$ in eq 1, then $k_{-2}$ and $k_{-1}$ in mechanism $\underline{\mathbf{E}}$ or $k^{\prime}-1$ in mechanism $\underline{\mathbf{F}}$ must be larger than $k_{\mathrm{d}}$ (or else 1a could not be isolated in the reaction of $\left[\mathrm{L}^{\mathrm{Me}} \mathrm{FeCl}\right]_{2}$ and $\mathrm{KHBEt}_{3}$ ). Therefore $k_{1}$ or $k_{2}$ (in $\underline{\mathbf{E}}$ ) or $k_{1}^{\prime}$ (in $\underline{\mathbf{F}}$ ) is rate-limiting. In other words, the rate determining step (RDS) must happen before the formation of $\mathrm{L}^{\mathrm{Me}} \mathrm{Fe}\left(\mathrm{HBEt}_{3}\right)$.

$\underline{\mathbf{E}}$ if RDS is $k_{1}$,

$$
\text { rate }=k_{1}[\mathbf{1 a}]
$$

if RDS is $k_{2}$,

$$
\text { rate }=k_{2} K_{\mathrm{eq}}{ }^{1 / 2}[\mathbf{1 a}]^{1 / 2}\left[\mathrm{BEt}_{3}\right] \text { where } K_{\mathrm{eq}}=k_{1} / k_{-1}
$$

Mechanism $\underline{\mathbf{E}}$ predicts a zero-order dependence on [BEt 3 ] if $k_{1}$ is the RDS or a half-order dependence on [1a] if $k_{2}$ is the RDS (eq 6). Neither situation agrees with the observed rate law.

In $\underline{\mathbf{F}}$, as shown in Scheme 8, the hydride dimer first reacts with one molecule of $\mathrm{BEt}_{3}$, going through transition state $\mathbf{a}^{*}$ to give $\mathrm{L}^{\mathrm{Me}} \mathrm{FeHBEt}_{3}$ and $\mathrm{L}^{\mathrm{Me}} \mathrm{FeH}$. The $\mathrm{L}^{\mathrm{Me}} \mathrm{FeH}$ monomer rapidly reacts with another molecule of $\mathrm{BEt}_{3}$ to form a second equivalent of $\mathrm{L}^{\mathrm{Me}} \mathrm{FeHBEt}_{3}$. The two $\mathrm{L}^{\mathrm{Me}} \mathrm{FeHBEt}_{3}$ species then undergo disproportionation to give the final products. If $k_{1}^{\prime}$ is ratelimiting the rate law is $\underline{\mathbf{F}}$

$$
\text { rate }=k_{1}{ }^{\prime}[\mathbf{1 a}]\left[\mathrm{BEt}_{3}\right]
$$

The first order dependence predicted for $[\mathbf{1 a}]$ and $\left[\mathrm{BEt}_{3}\right]$ is consistent with the experimental rate law. Moreover, the transition state $\mathbf{a}^{*}$ involves the dissociation of one $\mathrm{Fe}-\mathrm{H}$ bond and the 
formation of one B-H bond. As such, it bears a resemblance to the transition state for an interchange mechanism for substitution at a transition-metal complex (the intermediate stage between associative and dissociative substitution reactions). For $\mathrm{I}_{\mathrm{a}}$ or $\mathrm{I}_{\mathrm{d}}$ mechanisms, values of $\Delta \mathrm{S}^{\ddagger}$ near zero are common. ${ }^{28}$

Mechanism $\mathbf{F}$ is also consistent with other mechanistic data. With the opening of one ironhydride bond, the $\beta$-diketiminate has more space to avoid steric interactions with the borane $\mathrm{R}$ group. This explains the similar observed reaction rate for $\mathrm{BEt}_{3}$ and $\mathrm{BPh}_{3}$. Finally, there are no ionic intermediates prior to the rate-determining-step, which agrees with the lack of a solvent polarity effect during the reaction. Based on the above analysis, mechanism $\underline{\mathbf{F}}$ is the one most consistent with all experimental data.

Because the key disproportionation step lies after the rate-limiting step, kinetic data are not useful in elucidating its characteristics. Therefore, we endeavored to independently synthesize $\mathrm{L}^{\mathrm{Me}} \mathrm{Fe}^{+} \mathrm{BEt}^{-}{ }_{4}$, the putative intermediate in the reaction. ${ }^{29} \mathrm{First}$, reaction of $\left[\mathrm{L}^{\mathrm{Me}} \mathrm{FeCl}\right]_{2}$ and $\mathrm{NaBEt}_{4}$ in $\mathrm{Et}_{2} \mathrm{O}$ leads cleanly to the formation of $\mathrm{L}^{\mathrm{Me}} \mathrm{FeEt}$, as observed by ${ }^{1} \mathrm{H} \mathrm{NMR}$ spectroscopy. Also, $\mathrm{L}^{\mathrm{Me}} \mathrm{FeEt}$ does not react with $\mathrm{BEt}_{3}$ up to $120^{\circ} \mathrm{C}$. This is a thermodynamic phenomenon rather than a kinetic barrier, because heating $\mathrm{L}^{\mathrm{Me}} \mathrm{FePh}$ to $80^{\circ} \mathrm{C}$ for $3 \mathrm{~h}$ with one equiv of $\mathrm{BEt}_{3}$ gives a mixture of $\mathrm{L}^{\mathrm{Me}} \mathrm{FePh}$ and $\mathrm{L}^{\mathrm{Me}} \mathrm{FeEt}$. These experiments strongly suggest that transient $\mathrm{L}^{\mathrm{Me}} \mathrm{Fe}^{+} \mathrm{BR}_{4}{ }^{-}$species are unstable with respect to dissociation of borane, as required in the last step of mechanism $\underline{\mathbf{F}}$. In benzene, the ionic species may exist as a contact ion pair or as a tight ion pair, analogous to one that was previously observed. ${ }^{30}$

In summary, the available kinetic and mechanistic evidence are most consistent with mechanism $\mathbf{F}$, in which a transient ring-opened isomer of $\mathbf{1 a}$ reacts with $\mathrm{BR}_{3}$ to give $\mathrm{LFeHBR}_{3}$, which converts into the iron hydridoborate and iron alkyl products through the ionic intermediate $\mathrm{LFeBR}_{4}$.

\section{$\mathrm{L}^{\mathrm{Me}} \mathrm{Fe}(\mu-\mathrm{H})_{2} \mathrm{BEt}_{2}$ reactivity with hydrazine: $\mathrm{N}-\mathrm{N}$ bond cleavage}

Exploration of the reactivity of the dihydridoborate complex $\mathrm{L}^{\mathrm{Me}} \mathrm{Fe}(\mu-\mathrm{H})_{2} \mathrm{BEt}_{2}$ (2a) has shown an interesting series of reactions upon the addition of hydrazine. At room temperature, complex 2a reacts rapidly with $\mathrm{H}_{2} \mathrm{NNH}_{2}$ to give a hydrazine adduct, $\mathrm{L}^{\mathrm{Me}} \mathrm{Fe}\left(\eta^{1}-\mathrm{H}_{2} \mathrm{NNH}_{2}\right)(\mu-\mathrm{H})_{2} \mathrm{BEt}_{2}$ (4), isolated in $90 \%$ yield. Titration of hydrazine into a solution of $2 \mathrm{a}$ gave solutions with ${ }^{1} \mathrm{H}$ NMR spectra similar to 2a but variable chemical shifts, showing that the bound hydrazine is in rapid exchange with free hydrazine. Proton NMR resonances for the N-bound protons are not seen because of their proximity to the paramagnetic metal center.

The binding stoichiometry in solution can be determined by Job plot analysis, where small aliquots of hydrazine are added to $\mathbf{2 a}$ and the ${ }^{1} \mathrm{H}$ NMR spectrum is recorded after each addition. The chemical shift of peaks near $-260 \mathrm{ppm}$ and $19 \mathrm{ppm}$ vary depending on the ratio of $\mathrm{H}_{2} \mathrm{NNH}_{2}$ and 2a (Figure 4). The intersection of the initial line (deficiency of hydrazine) and final line (deficiency of 2a) shows that the two molecules bind in a 1:1 manner.

Figure 5 displays the $\mathrm{X}$-ray crystal structure of 4 . The hydrazine ligand binds to the iron atom in a $\eta^{1}$ mode and points towards the diketiminate. The bridging hydrogen atoms were again located in Fourier difference maps, and their positions were refined. The geometry of the fivecoordinate iron atom is intermediate between ideal square-pyramidal and trigonal-bipyramidal with $\tau=0.43^{31}$. With the higher coordination number at iron, the $\mathrm{Fe}-\mathrm{H}$ distances increase to 1.82(2) $\AA$ and 1.91(2) $\AA$, which are about $0.1 \AA$ longer than those in 1 . Accordingly, the H-B distances decrease by $0.12 \AA$ to $1.22(2) \AA$, comparable to the average value for literature hydridoborate complexes (see Supporting Information). The FTIR spectrum of $\mathbf{4}$ shows two bands at $3368 \mathrm{~cm}^{-1}$ and $3333 \mathrm{~cm}^{-1}$, which shifted to $2519 \mathrm{~cm}^{-1}$ and $2493 \mathrm{~cm}^{-1}$ when $\mathrm{N}_{2} \mathrm{D}_{4}$ 
was used (calculated from harmonic oscillator: $2460 \mathrm{~cm}^{-1}$ and $2434 \mathrm{~cm}^{-1}$ ). Therefore, these are assigned as N-H (N-D) stretching vibrations. 32

Well-characterized complexes of iron with $\mathrm{N}_{2}$ and its partial reduction products $\mathrm{N}_{2} \mathrm{H}_{2}$ and $\mathrm{N}_{2} \mathrm{H}_{4}$ are rare. A search of the Cambridge Structural Database showed only eight examples of Fe- $\mathrm{N}_{2} \mathrm{H}_{4}$ species. 32,33 The Fe-N distance in our complex is 2.214(2) $\AA$, which is comparable to the average value of 2.14(3) $\AA$ for the known iron-hydrazine adducts. The N-N distance in 4 also agrees well with the average literature value of 1.448(3) $\AA$ for bound $\mathrm{N}_{2} \mathrm{H}_{4}$.

After heating a solution of 4 in toluene at $60{ }^{\circ} \mathrm{C}$ for $22 \mathrm{~h}$, the new complex $\mathrm{L}^{\mathrm{Me}} \mathrm{Fe}(\mu$ $\left.\mathrm{NH}_{2}\right)_{2} \mathrm{BEt}_{2}(\mathbf{5})$ can be isolated in $57 \%$ yield (Scheme 9). The solid-state structure of $\mathbf{5}$ is shown in Figure 6. Interestingly, the N-N bond has been cleaved $\left(\mathrm{N}^{\cdots \cdots} \mathrm{N}=2.459(3) \AA\right)$ to yield a diaminoborate complex. The IR spectrum shows a single $\mathrm{N}-\mathrm{H}$ stretching band at $3393 \mathrm{~cm}^{-1}$, which shifts to $2494 \mathrm{~cm}^{-1}$ in the compound synthesized from $\mathrm{N}_{2} \mathrm{D}_{4}$. Most complexes containing $\mathrm{M}\left(\mu-\mathrm{NH}_{2}\right)_{2} \mathrm{M}$ fragments exhibit two $\mathrm{N}-\mathrm{H}$ stretching bands between 3100-3300 $\mathrm{cm}^{-1.34}$

The observation of one $\mathrm{N}-\mathrm{H}$ stretching band suggests a possible alternative formulation for 5, $\mathrm{L}^{\mathrm{Me}} \mathrm{Fe}(\mu-\mathrm{NH})_{2} \mathrm{BEt}_{2}$. However, this formally iron(IV) complex seems less likely for several reasons. First, all examples of tetrahedral iron(IV) in the literature are low-spin and supported by strongly donating terminal nitride or imide ligands. ${ }^{35}$ The solution magnetic moment of 5 is 4.8(1) $\mu_{\mathrm{B}}$, which is more consistent with a high-spin Fe(II) complex. Second, each of the four N-bound $\mathrm{H}$ atoms was clearly visible in Fourier maps from the X-ray diffraction experiment and was refined. ${ }^{36}$ Finally, the alternative formulation implies that 2 equiv of $\mathrm{H}_{2}$ are produced in the reaction. Using gas chromatography, we determined that only $1.67 \pm 0.03$ equiv of $\mathrm{H}_{2}$ is produced (see Supporting Information for details), inconsistent with the diimidoborate formulation.

We have no definitive explanation for the observation of $\mathrm{H}_{2}$ in excess of the amount predicted by the stoichiometry of the reaction in Scheme 9. No substantial amount of $\mathrm{H}_{2}$ was produced in control experiments where 2a was heated with hydrazine. However, it is important to note that the spectroscopic yield of $\mathbf{5}$ is only $60 \%$ (from an NMR experiment with internal standard). A substantial amount of a black precipitate is formed along with $\mathbf{5}$. It seems possible that the remaining 0.4 equiv of hydrazine is disproportionated to $\mathrm{H}_{2}$ and $\mathrm{N}_{2}$ by the iron byproducts, with complete disproportionation giving the limiting stoichiometry in Scheme 10. The rough agreement with the observed $\mathrm{H}_{2}$ production supports this speculation.

Because $\mathbf{4}$ has hydrogens in the hydride bridges as well as the bound hydrazine, a final question regards the source of the $\mathrm{N}-\mathrm{H}$ protons in $\mathbf{5}$. Importantly, the synthesis of $\mathbf{5}$ from $\mathrm{N}_{2} \mathrm{D}_{4}$ gave a product with no $\mathrm{N}-\mathrm{H}$ peak and a new N-D peak in the infrared spectrum. This observation indicates that all $\mathrm{N}-\mathrm{H}$ protons in $\mathbf{5}$ derive from hydrazine, and that the bridging hydrides in $\mathbf{4}$ are released as $\mathrm{H}_{2}$ upon heating. Although the unknown nature of some products dissuades us from further mechanistic studies, one can speculate a mechanism where loss of $\mathrm{H}_{2}$ from 4 generates unsaturation at iron and boron. This would enable coordination of the free lone pair on the bound hydrazine, followed by N-N cleavage to give $\mathbf{5}$. However, we stress that other mechanisms are also consistent with the limited data.

A limited number of literature examples report the cleavage of hydrazine $\mathrm{N}-\mathrm{N}$ bonds with metal-containing clusters, often through formation of bridging $\mathrm{NH}$ or $\mathrm{NH}_{2} .37$ There are even fewer complexes that cleanly perform this reaction with two or less metals. 38 Here, the Fe-N interactions are reinforced by the low-coordinate environment, which creates strong bonds to electronegative groups, as we have demonstrated previously. ${ }^{12}$ 


\section{Conclusions}

We have discovered an interesting series of borane alkylations/arylations of iron hydride complexes, which give iron hydridoborate products through attack of a ring-opened iron hydride species on a borane. In this reaction, the hydride ligand acts as a nucleophile, apparently activating the borane toward transfer of the $\mathrm{R}$ group to iron. A combination of kinetics studies has been unusually informative with respect to the mechanism, elucidating the nature of the rate-determining transition state. In addition, the hydridoborate product of the reaction reacts to cleave the N-N bond of hydrazine, releasing the two bridging hydrides as $\mathrm{H}_{2}$. The $\mathrm{B}-\mathrm{C}$ and $\mathrm{N}-\mathrm{N}$ cleavage reactions demonstrate the ability of low-coordinate iron complexes to perform difficult bond transformations under mild conditions.

\section{Experimental Section}

\section{General Considerations}

All manipulations were performed unde $\mathrm{r}$ a nitrogen atmosphere using standard Schlenk techniques or in an M. Braun glovebox maintained at or below 1 ppm of $\mathrm{O}_{2}$ and $\mathrm{H}_{2} \mathrm{O}$. Glassware was dried at $150{ }^{\circ} \mathrm{C}$ overnight. ${ }^{1} \mathrm{H}$ NMR spectra were recorded on a Bruker Avance 500 spectrometer $(500 \mathrm{MHz})$ at $22{ }^{\circ} \mathrm{C}$ and referenced internally to residual protiated solvent $\left(\mathrm{C}_{6} \mathrm{D}_{5} \mathrm{H}\right.$ at $\left.7.15 \mathrm{ppm}\right)$. Resonances are broad singlets unless otherwise specified. Infrared spectra (450-4000 $\mathrm{cm}^{-1}$ ) were recorded on $\mathrm{KBr}$ pellet samples in a Shimadzu FTIR spectrophotometer (FTIR-8400S). A total of 32 scans at $2 \mathrm{~cm}^{-1}$ resolution were collected in each case. Electronic spectra were recorded between $280 \mathrm{~nm}$ and $1000 \mathrm{~nm}$ on a Cary $50 \mathrm{UV}$ visible spectrophotometer, using screw-cap quartz cuvettes of $1 \mathrm{~cm}$ optical path length. Elemental analyses were determined by Desert Analytics (Tucson, AZ). Pentane, tetrahydrofuran (THF), and toluene were purified by passage through activated alumina and "deoxygenizer" columns obtained from Glass Contour Co. (Laguna Beach, CA). Deuterated benzene and THF were dried over $\mathrm{CaH}_{2}$, then over $\mathrm{Na} /$ benzophenone, and then vacuum transferred into a storage container. Before use, an aliquot of each solvent was tested with a drop of sodium benzophenone ketyl in THF solution. Celite was dried overnight at $200{ }^{\circ} \mathrm{C}$ under vacuum. Hydrazine, purchased from Aldrich, was dried over $\mathrm{KH}$ and vacuum transferred before use. $\mathrm{KH}$, purchased for Aldrich as suspensions in oil, was washed with pentane three times and dried. $\mathrm{BEt}_{3}(1.0 \mathrm{M}$ in hexane) was purchased from Aldrich and used as it arrived without any further purification. The preparation and properties of $\left[\mathrm{L} \mathrm{Me}^{\mathrm{FeCl}}\right]_{2},\left[\mathrm{~L} \mathrm{Me}^{\mathrm{FeH}}\right]_{2}$ (1) and $\mathrm{KHBEt}_{3}$ were previously reported. ${ }^{39}$

\section{$L^{\mathrm{Me}} \mathrm{Fe}(\mu-\mathrm{H})_{2} \mathrm{BEt}_{2}(2 \mathrm{a})$ from 1}

A sample of 1 (139 mg, $0.147 \mathrm{mmol}$ ) was dissolved in $15 \mathrm{~mL}$ of toluene. Triethylborane ( 0.29 $\mathrm{mL}$ of a $1.0 \mathrm{M}$ solution in hexane) was added via syringe to the bright red solution. The solution was heated at $70{ }^{\circ} \mathrm{C}$ for $14 \mathrm{~h}$. Volatile materials were removed under vacuum and the residue was extracted with pentane $(15 \mathrm{~mL})$, filtered and concentrated to $5 \mathrm{~mL}$. Crystallization from pentane at $-35^{\circ} \mathrm{C}$ gave bright red needles $(68 \mathrm{mg}, 72 \%)$.

\section{$L^{\mathrm{Me}} \mathrm{Fe}(\mu-\mathrm{H})_{2} \mathrm{BEt}_{2}(2 \mathrm{a})$ from $\mathrm{FeCl}_{2}$}

The compound was typically synthesized in one flask from $\mathrm{L}^{\mathrm{Me}} \mathrm{Li}$ and $\mathrm{Fe}(\mathrm{THF}){ }_{1.5} \mathrm{Cl}_{2}$ as follows. A Schlenk flask was loaded with a mixture of $\mathrm{L}^{\mathrm{Me}} \mathrm{Li}(1.69 \mathrm{~g}, 3.98 \mathrm{mmol})$ and $\mathrm{Fe}$ (THF) ${ }_{1.5} \mathrm{Cl}_{2}(0.94 \mathrm{~g}, 4.0 \mathrm{mmol})$ in toluene $(50 \mathrm{~mL})$. The mixture was stirred at $80^{\circ} \mathrm{C}$ for $22 \mathrm{~h}$. All solvent was removed under vacuum and a solution of $\mathrm{KHBEt}_{3}(0.56 \mathrm{~g}, 4.0 \mathrm{mmol})$ in toluene $(50 \mathrm{~mL})$ was added. The mixture was heated at $80^{\circ} \mathrm{C}$ for $4 \mathrm{~h}$. Volatile materials were removed under vacuum and the residue was extracted with pentane $(100 \mathrm{~mL})$, filtered and concentrated to $20 \mathrm{~mL}$. Crystallization at $-35{ }^{\circ} \mathrm{C}$ gave bright red needles $(777 \mathrm{mg}, 72 \%) .{ }^{1} \mathrm{H}$ NMR (400 $\left.\mathrm{MHz}, \mathrm{C}_{6} \mathrm{D}_{6}\right): 81\left(6 \mathrm{H}, \mathrm{BEt}_{2} \mathrm{CH}_{3}\right), 46\left(6 \mathrm{H}\right.$, backbone $\left.\mathrm{CH}_{3}\right), 17(4 \mathrm{H}),-4\left(12 \mathrm{H}, i \operatorname{Pr} \mathrm{CH}_{3}\right),-36$ 
$(12 \mathrm{H}, i \mathrm{Pr} \mathrm{CH} 3),-40(4 \mathrm{H}),-50(2 \mathrm{H}, \mathrm{p}-\mathrm{H}),-208(4 \mathrm{H}) \mathrm{ppm}$. (Peaks integrated as $4 \mathrm{H}$ could be $\mathrm{BEt}_{2} \mathrm{CH}_{2}, \mathrm{~m}-\mathrm{H}$ or ${ }^{\mathrm{i}} \mathrm{Pr}$ methine. Peaks for the backbone $\mathrm{H}$ and bridging $\mathrm{H}$ were not observed.) UV-vis (pentane): $299\left(\varepsilon=27.3 \mathrm{mM}^{-1} \mathrm{~cm}^{-1}\right), 398\left(\varepsilon=15.0 \mathrm{mM}^{-1} \mathrm{~cm}^{-1}\right), 554(\varepsilon=2.9$

$\left.\mathrm{mM}^{-1} \mathrm{~cm}^{-1}\right) \mathrm{nm}$. $\mu_{\mathrm{eff}}\left(\mathrm{C}_{6} \mathrm{D}_{6}, 25^{\circ} \mathrm{C}\right): 5.1(1) \mu_{\mathrm{B}}$. Elem. Anal. Calcd for $\mathrm{C}_{33} \mathrm{H}_{53} \mathrm{~N}_{2} \mathrm{BFe}: \mathrm{C}, 72.80$; H, 9.81; N, 5.15. Found: C, 73.52; H, 9.52; N, 5.62.

\section{$\mathrm{L}^{\mathrm{Me}} \mathrm{Fe}(\mu-\mathrm{H})_{2} \mathrm{BPh}_{2}(2 \mathrm{~b})$}

$1(127 \mathrm{mg}, 0.13 \mathrm{mmol})$ and triphenylborane $(32 \mathrm{mg}, 0.13 \mathrm{mmol})$ were dissolved in $20 \mathrm{~mL}$ of toluene. The solution was heated at $80^{\circ} \mathrm{C}$ for $18 \mathrm{~h}$. Volatile materials were removed under vacuum and the residue was extracted with toluene $(15 \mathrm{~mL})$, filtered and concentrated to $5 \mathrm{~mL}$. Crystallization from pentane at $-26{ }^{\circ} \mathrm{C}$ gave red blocks $(56 \mathrm{mg}, 67 \%) .{ }^{1} \mathrm{H}$ NMR $(500 \mathrm{MHz}$, $\left.\mathrm{C}_{6} \mathrm{D}_{6}\right): 78\left(6 \mathrm{H}\right.$, backbone $\left.\mathrm{CH}_{3}\right), 32(4 \mathrm{H}), 17(4 \mathrm{H}+4 \mathrm{H}),-4\left(12 \mathrm{H}, i \mathrm{Pr} \mathrm{CH}_{3}\right),-8(2 \mathrm{H}),-40(12 \mathrm{H}$, $\left.i \mathrm{Pr} \mathrm{CH} \mathrm{CH}_{3}\right),-46(4 \mathrm{H}),-52(2 \mathrm{H}) \mathrm{ppm}$. (Peaks integrated as $4 \mathrm{H}$ could be $i \mathrm{Pr}$ methine, aryl $m-\mathrm{H}$, phenyl $o-\mathrm{H}$ or phenyl $m-\mathrm{H}$. Peaks integrated as $2 \mathrm{H}$ could be aryl $p-\mathrm{H}$ or phenyl $p-\mathrm{H}$. Peaks for the backbone $\mathrm{H}$ and bridging $\mathrm{H}$ were not observed.) UV-vis (toluene): 291 ( $\varepsilon=14.6$ $\left.\mathrm{mM}^{-1} \mathrm{~cm}^{-1}\right), 398\left(\varepsilon=6.3 \mathrm{mM}^{-1} \mathrm{~cm}^{-1}\right), 567\left(\varepsilon=1.2 \mathrm{mM}^{-1} \mathrm{~cm}^{-1}\right)$ nm. $\mu_{\mathrm{eff}}\left(\mathrm{C}_{6} \mathrm{D}_{6}, 25^{\circ} \mathrm{C}\right): 4.0$ (1) $\mu_{\mathrm{B}}$. Elem. Anal. Calcd for $\mathrm{C}_{41} \mathrm{H}_{53} \mathrm{BFeN}_{2}$ : C, 77.12; H, 8.05; N, 4.39. Found: C 76.88, H $7.85, \mathrm{~N} 4.38$,

\section{$\mathrm{L}^{\mathrm{tBu}} \mathrm{Fe}(\mu-\mathrm{H})_{2} \mathrm{BEt}_{2}(2 \mathrm{c})$}

A Schlenk flask was loaded with a mixture of $\mathrm{L}^{\mathrm{tBu}} \mathrm{FeCl}(722 \mathrm{mg}, 1.21 \mathrm{mmol})$ and $\mathrm{KHBEt}_{3}$ $(167 \mathrm{mg}, 1.21 \mathrm{mmol})$ in toluene $(50 \mathrm{~mL})$. The mixture was stirred at $80^{\circ} \mathrm{C}$ for $18 \mathrm{~h}$. Volatile materials were removed under vacuum and the residue was extracted with pentane $(50 \mathrm{~mL})$, filtered and concentrated to $10 \mathrm{~mL}$. Crystallization at $-26^{\circ} \mathrm{C}$ gave dark red blocks ( $224 \mathrm{mg}$, 59\%). ${ }^{1} \mathrm{H}$ NMR (500 MHz, $\left.\mathrm{C}_{6} \mathrm{D}_{6}\right): 71\left(6 \mathrm{H}, \mathrm{BEt}_{2} \mathrm{CH}_{3}\right), 42$ (1H, backbone), 35 (18H, backbone $\left.\mathrm{CH}_{3}\right), 16(4 \mathrm{H}),-13\left(12 \mathrm{H}, i \mathrm{Pr} \mathrm{CH}_{3}\right),-61(12 \mathrm{H}, i \mathrm{Pr} \mathrm{CH})_{3},-66(4 \mathrm{H}),-89(2 \mathrm{H}, \mathrm{p}-\mathrm{H}),-313(4 \mathrm{H})$ ppm. (Peaks integrated as $4 \mathrm{H}$ could be $\mathrm{BEt}_{2} \mathrm{CH}_{2}, \mathrm{~m}-\mathrm{H}$ or $i \mathrm{Pr}$ methine. Peaks for the bridging $\mathrm{H}$ were not observed.) UV-vis (pentane): $333\left(\varepsilon=9.42 \mathrm{mM}^{-1} \mathrm{~cm}^{-1}\right), 414(\varepsilon=6.82$ $\left.\mathrm{mM}^{-1} \mathrm{~cm}^{-1}\right), 597\left(\varepsilon=1.27 \mathrm{mM}^{-1} \mathrm{~cm}^{-1}\right) \mathrm{nm} . \mu_{\mathrm{eff}}\left(\mathrm{C}_{6} \mathrm{D}_{6}, 25^{\circ} \mathrm{C}\right): 5.7(1) \mu_{\mathrm{B}}$. Elem. Anal. Calcd for $\mathrm{C}_{39} \mathrm{H}_{65} \mathrm{~N}_{2} \mathrm{BFe}$ : C, 74.52; H, 10.42; N, 4.46. Found: C, 74.60; H 10.20; N, 4.34.

Complexes $3 \mathbf{a}$ and $\mathbf{3 c}$ have been reported in ref 12 .

\section{$\mathrm{L}^{\mathrm{Me}} \mathrm{FePh}(3 \mathrm{~b})$}

The compound was typically synthesized in one flask from $\mathrm{L}^{\mathrm{Me}} \mathrm{Li}$ and $\mathrm{FeCl}_{2}(\mathrm{THF})_{1.5}$ as follows. A resealable flask was loaded with a mixture of $\mathrm{L}^{\mathrm{Me}} \mathrm{Li}(592 \mathrm{mg}, 1.4 \mathrm{mmol})$ and $\mathrm{FeCl}_{2}(\mathrm{THF})_{1.5}(329 \mathrm{mg}, 1.4 \mathrm{mmol})$ in toluene $(20 \mathrm{~mL})$. The mixture was stirred at $80^{\circ} \mathrm{C}$ for $22 \mathrm{~h}$. Phenylmagnesium chloride ( $2.0 \mathrm{M}$ in THF, $0.7 \mathrm{~mL}, 1.4 \mathrm{mmol}$ ) was added, and the mixture was stirred for $4 \mathrm{~h}$ at room temperature. Solvent was removed under vacuum. The residue was extracted with pentane $(20 \mathrm{~mL})$, filtered through Celite, concentrated to $3 \mathrm{~mL}$, and cooled to $-45^{\circ} \mathrm{C}$ to give bright yellow crystals $(487 \mathrm{mg}, 63 \%$ yield $) .{ }^{1} \mathrm{H}$ NMR $\left(\mathrm{C}_{6} \mathrm{D}_{6}, 21{ }^{\circ} \mathrm{C}\right): 163(2 \mathrm{H}$, phenyl $m-\mathrm{CH}), 126(1 \mathrm{H}$, phenyl $p-\mathrm{CH}), 47\left(6 \mathrm{H}\right.$, backbone $\left.\mathrm{CH}_{3}\right), 28(1 \mathrm{H}$, backbone $\mathrm{CH}),-10$ $(4 \mathrm{H}, m-\mathrm{CH}),-21(12 \mathrm{H}, i \operatorname{Pr~CH} 3),-82(2 \mathrm{H}, p-\mathrm{CH}),-118(4 \mathrm{H}, i \operatorname{Pr~CH}),-125\left(12 \mathrm{H}, i \mathrm{Pr} \mathrm{CH}_{3}\right)$. (Phenyl $o$ - $\mathrm{CH}$ was not observed. Peak assignments were based on integrations and ${ }^{1} \mathrm{H}$ NMR spectra of other known $\mathrm{L}^{\mathrm{Me}} \mathrm{FeR}$ complexes.) UV-vis (pentane): $325\left(\varepsilon=15.6 \mathrm{mM}^{-1} \mathrm{~cm}^{-1}\right)$, $368\left(\varepsilon=11.4 \mathrm{mM}^{-1} \mathrm{~cm}^{-1}\right), 494\left(\varepsilon=1.0 \mathrm{mM}^{-1} \mathrm{~cm}^{-1}\right)$ nm. $\mu_{\mathrm{eff}}\left(\mathrm{C}_{6} \mathrm{D}_{6}, 25^{\circ} \mathrm{C}\right): 5.2(1) \mu_{\mathrm{B}}$. Elem. Anal. Calcd for $\mathrm{C}_{35} \mathrm{H}_{46} \mathrm{~N}_{2} \mathrm{Fe}$ : C 76.35, H 8.42, N 5.09. Found: C, 76.06; H, 8.20; N, 4.99.

\section{$\mathrm{L}^{\mathrm{Me}} \mathrm{Fe}\left(\mathrm{H}_{2} \mathrm{NNH}_{2}\right)(\boldsymbol{\mu}-\mathrm{H})_{2} \mathrm{BEt}_{2}$ (4)}

$\mathrm{L}^{\mathrm{Me}} \mathrm{Fe}(\mu-\mathrm{H})_{2} \mathrm{BEt}_{2}(221 \mathrm{mg}, 0.407 \mathrm{mmol})$ was dissolved in diethyl ether $(10 \mathrm{~mL})$. Hydrazine $(13 \mu \mathrm{L}, 0.41 \mathrm{mmol})$ was added via syringe to the bright red solution. The solution was shaken, 
causing an immediate color change from bright red to orange-pink. The solution was concentrated to $2 \mathrm{~mL}$ and cooled to $-35^{\circ} \mathrm{C}$ to give bright pink-yellow needles of $3(212 \mathrm{mg}$, 90\%). ${ }^{1} \mathrm{H}$ NMR (400 MHz, $\left.\mathrm{C}_{6} \mathrm{D}_{6}\right): 24(6 \mathrm{H}), 19(4 \mathrm{H}), 3\left(12 \mathrm{H}, i \mathrm{Pr} \mathrm{CH}_{3}\right), 1(6 \mathrm{H}),-15(12 \mathrm{H}, i \mathrm{Pr}$ $\left.\mathrm{CH}_{3}\right),-24(4 \mathrm{H}),-40(2 \mathrm{H}, \mathrm{p}-\mathrm{H}),-62(1 \mathrm{H}$, backbone $\mathrm{C}-\mathrm{H}),-260(4 \mathrm{H}) \mathrm{ppm}$. (Peaks integrated as $4 \mathrm{H}$ could be $\mathrm{BEt}_{2} \mathrm{CH}_{2}, \mathrm{~m}-\mathrm{H}$ or $i \mathrm{Pr}$ methine. Peaks integrated as $6 \mathrm{H}$ could be $\mathrm{BEt}_{2} \mathrm{CH}_{3}$ or backbone $\mathrm{CH}_{3}$. Peaks for the bridging $\mathrm{H}$ and hydrazine $\mathrm{H}$ were not observed.) $\mathrm{IR}$ ( $\mathrm{KBr}$ pellet): $3368 \mathrm{~cm}^{-1}, 3338 \mathrm{~cm}^{-1}(\mathrm{~N}-\mathrm{H})$. UV-vis (pentane): $298\left(\varepsilon=13.4 \mathrm{mM}^{-1} \mathrm{~cm}^{-1}\right), 397(\varepsilon=7.5$ $\left.\mathrm{mM}^{-1} \mathrm{~cm}^{-1}\right), 552\left(\varepsilon=1.5 \mathrm{mM}^{-1} \mathrm{~cm}^{-1}\right)$ nm. $\mu_{\mathrm{eff}}\left(\mathrm{C}_{6} \mathrm{D}_{6}, 25^{\circ} \mathrm{C}\right): 3.8(1) \mu_{\mathrm{B}}$. Elem. Anal. Calcd for $\mathrm{C}_{33} \mathrm{H}_{57} \mathrm{~N}_{4} \mathrm{BFe}$ : C, 68.75; H, 9.97; N, 9.72. Found: C, 68.01; H, 8.83; N, 5.70. The bound hydrazine could be removed by extended pumping under vacuum (i.e. $50 \%$ hydrazine was removed after $26 \mathrm{~h}$ at RT), and we suspect that this is the reason for the low nitrogen analysis.

\section{$\mathrm{L}^{\mathrm{Me}} \mathrm{Fe}\left(\mu-\mathrm{NH}_{2}\right)_{2} \mathrm{BEt}_{2}(5)$}

A sample of $\mathrm{L}^{\mathrm{Me}} \mathrm{Fe}(\mu-\mathrm{H})_{2} \mathrm{BEt}_{2}$ (201 $\left.\mathrm{mg}, 0.371 \mathrm{mmol}\right)$ was dissolved in toluene $(15 \mathrm{~mL})$. Hydrazine ( $14 \mu \mathrm{L}, 0.45 \mathrm{mmol}$ ) was added via syringe to the bright red solution. The solution was shaken and then heated at $60^{\circ} \mathrm{C}$ for $22 \mathrm{~h}$. Volatile materials were removed under vacuum and the residue was extracted with pentane $(15 \mathrm{~mL})$, filtered and concentrated to $2 \mathrm{~mL}$. Crystallization from pentane at $-35^{\circ} \mathrm{C}$ gave brown blocks (121.6 mg, 57\%). ${ }^{1} \mathrm{H}$ NMR (500 $\left.\mathrm{MHz}, \mathrm{C}_{6} \mathrm{D}_{6}\right): 57(4 \mathrm{H}), 33(6 \mathrm{H}), 19(4 \mathrm{H}), 2\left(12 \mathrm{H}, i \mathrm{Pr} \mathrm{CH}_{3}\right),-20\left(12 \mathrm{H}, i \operatorname{Pr~CH}_{3}\right),-35(4 \mathrm{H}),-42$ $(1 \mathrm{H}$, backbone $\mathrm{C}-\mathrm{H}),-49(2 \mathrm{H}, \mathrm{p}-\mathrm{H}),-71(6 \mathrm{H}) \mathrm{ppm}$. (Peaks integrated as $4 \mathrm{H}$ could be $\mathrm{BEt}_{2}$ $\mathrm{CH}_{2}, \mathrm{~m}-\mathrm{H}$ or $i \mathrm{Pr}$ methine. Peaks integrated as $6 \mathrm{H}$ could be $\mathrm{BEt}_{2} \mathrm{CH}_{3}$ or backbone $\mathrm{CH}_{3}$. Peaks for the bridging $\mathrm{NH}_{2}$ groups were not observed.) IR (KBr pellet): $3393 \mathrm{~cm}^{-1}(\mathrm{~N}-\mathrm{H})$. UV-vis (pentane): $331\left(\varepsilon=16.0 \mathrm{mM}^{-1} \mathrm{~cm}^{-1}\right) . \mu_{\mathrm{eff}}\left(\mathrm{C}_{6} \mathrm{D}_{6}, 25^{\circ} \mathrm{C}\right): 4.8(1) \mathrm{mu} ;_{\mathrm{B}}$. Elem. Anal. Calcd for $\mathrm{C}_{33} \mathrm{H}_{55} \mathrm{~N}_{4} \mathrm{BFe}: \mathrm{C}, 68.99 ; \mathrm{H}, 9.65 ; \mathrm{N}, 9.75$. Found: $\mathrm{C}, 68.68 ; \mathrm{H}, 9.45 ; \mathrm{N}, 9.35$.

\section{Kinetic experiments: effect of $\mathrm{BEt}_{\mathbf{3}}$}

$\left[\mathrm{L}^{\mathrm{Me}} \mathrm{FeH}\right]_{2},(16.4 \mathrm{mg}, 17.3 \mathrm{mmol})$, was dissolved in $\mathrm{C}_{6} \mathrm{D}_{6}(2.0 \mathrm{~mL})$. A J. Young NMR tube, which was pre-dried at $180^{\circ} \mathrm{C}$, was loaded with $0.4 \mathrm{~mL}$ of the above iron hydride complex solution and $0.14 \mathrm{~mL}$ of $\mathrm{BEt}_{3}\left(1.0 \mathrm{M}\right.$ in hexane) $\mathrm{C}_{6} \mathrm{D}_{6}$ solution (with various $\mathrm{BEt}_{3}$ concentrations - see Supporting Information). The NMR tube was placed into the NMR probe, which was equilibrated at the appropriate temperature (typically $319.2 \mathrm{~K}$ ). After the sample had equilibrated for $2 \mathrm{~min},{ }^{1} \mathrm{H}$ NMR spectra were recorded at preset times using an automated program. After Fourier transform, phasing, calibrating and integrating each spectrum using MestRec, a plot of normalized [1] (y) vs. reaction time (x) was generated. Then these experimental data were fitted into the general, integrated equation: $\mathrm{y}_{0}+\mathrm{A}_{1} * \exp \left(-\mathrm{x} / \mathrm{t}_{1}\right)$, where $\mathrm{y}_{0}, \mathrm{~A}_{1}, \mathrm{t}_{1}$ are variables, $\mathrm{t}_{1}$ being the reciprocal of the first order rate constant. Origin 6.1 was employed for the data fitting. The error bars on the rate constant came from the least-squares fit to the data.

\section{Kinetic experiments: effect of $\left[\mathrm{L}^{\mathrm{Me}} \mathrm{FeH}\right]_{2}$}

$\mathrm{BEt}_{3}\left(1.34,1.0 \mathrm{M}\right.$ hexane solution) was mixed with $\mathrm{C}_{6} \mathrm{D}_{6}(1.86 \mathrm{~mL})$ and used as a stock solution. A pre-dried J. Young NMR tube was charged with different amounts of $\mathbf{1}$ and $\mathrm{BEt}_{3}$ ( $0.3 \mathrm{~mL}$ of standard solution), with a drop of metallic mercury (see text).

\section{Kinetic experiments: activation parameters}

In the range $280-300 \mathrm{~K}$, temperatures in the NMR probe were calibrated using $100 \%$ methanol; in the range $300-380 \mathrm{~K}, 100 \%$ ethylene glycol was used for calibrations (Bruker Instruments, VT-Calibration manual). 1a $(73.7 \mathrm{mg}, 77.7 \mathrm{mmol})$ was dissolved in $\mathrm{C}_{6} \mathrm{D}_{6}(1.86 \mathrm{~mL})$ then $\mathrm{BEt}_{3}(1.34 \mathrm{~mL}, 1.0 \mathrm{M}$ hexane solution) was added to make the reaction solution. For each temperature, $0.3 \mathrm{~mL}$ of the reaction solution was injected into a J. Young NMR tube with one drop of $\mathrm{Hg}^{0}$. The reaction solution was stored at $-35^{\circ} \mathrm{C}$ when it was not in use. 


\section{Supplementary Material}

Refer to Web version on PubMed Central for supplementary material.

\section{Acknowledgements}

This work was supported by the NSF (CHE-0134658 to P.L.H.), the NIH (GM-065313 to P.L.H.), and the University of Rochester (Weissberger Fellowship to Y.Y.). P.L.H. acknowledges an A. P. Sloan Fellowship. We thank Jeremy Smith for initial synthetic experiments, William Jones and Thomas Cundari for helpful discussions, Pingwu Du and Richard Eisenberg for assistance with GC equipment, and Christine Flaschenriem for collecting crystallographic data.

\section{References and Notes}

1. Dedieu, A., editor. Transition Metal Hydrides. VCH; New York: 1992. Peruzzini, M.; Poli, R., editors. Recent Advances in Hydride Chemistry. Elsevier; Amsterdam: 2001.

2. Maroney, MJ. Hydrogen Metabolism and Hydrogenase. In: Bertini, I.; Gray, HB.; Stiefel, EI.; Valentine, JS., editors. Biological Inorganic Chemistry. University Science Books; Sausalito, CA: 2007. p. 443-452.

3. a) Igarashi RY, Laryukhin M, Dos Santos PC, Lee H-I, Dean DR, Seefeldt LC, Hoffman BM. J Am Chem Soc 2005;127:6231-6241. [PubMed: 15853328] (b) Lukoyanov D, Barney BM, Dean DR, Seefeldt LC, Hoffman BM. Proc Natl Acad Sci USA 2007;104:1451-1455. [PubMed: 17251348]

4. a) Smith JM, Lachicotte RJ, Holland PL. J Am Chem Soc 2003;125:15752-15753. [PubMed: 14677959] (b) Vela J, Smith JM, Yu Y, Ketterer NA, Flaschenriem CJ, Lachicotte RJ, Holland PL. J Am Chem Soc 2005;127:7857-7870. [PubMed: 15913376]

5. A four-coordinate iron(II)-hydride complex has been implicated in the formation of a cyclohexadienyliron(II) complex: Brown SD, Peters JC. J Am Chem Soc 2004;126:4538-4539. [PubMed: 15070370]This insertion is analogous to the benzene reactivity of an isolated iron(II) silyl complex: Turculet L, Feldman JD, Tilley TD. Organometallics 2003;22:4627-4629.

6. Carey, RA.; Sundberg, RJ. Adavanced Organic Chemistry, Part B: Reactions and Synthesis. 4. Kluwer Academic/Plenum Publishers; New York: 2001. p. 549-563.

7. a) Miyaura N, Suzuki A. Chem Rev 1995;95:2457-83. (b) Chemler SR, Trauner D, Danishefsky SJ. Angew Chem, Int Ed 2001;40:4544-4568. (c) Hayashi H, Yamasaki K. Chem Rev 2003;103:2829_ 2844. [PubMed: 12914482]

8. Onak, T. Organoborane Chemistry. Academic; New York: 1975. Mikhailov, BM.; Bubnov, YN. Organoboron Compounds in Organic Synthesis. Hanvood Academic Publishers; Amsterdam: 1983. Pelter, A.; Smith, K.; Brown, HC. Borane Reagents. Academic; New York: 1988.

9. $\mathrm{BEt}_{4}{ }^{-}$has been used as an ethyl source for the synthesis of organometallics like tetraethyllead: (a) Honeycutt JB, Riddle JM. J Am Chem Soc 1961;83:369-373. (b) Fischer R, Rapsomanikis S, Andreae MR. Anal Chem 1993;65:763-766. [PubMed: 8460831] (c) Rapsomanikis S. Analyst 2004;119:1429_ 1439.

10. (a) Miyaura N. J Organomet Chem 2002;653:54-57. (b) Zhao P, Incarvito CD, Hartwig JF. J Am Chem Soc 2007;129:1876-1877. [PubMed: 17256944]

11. Identical product mixtures are obtained when $\left[\mathrm{L}^{\mathrm{R}} \mathrm{FeCl}\right]_{\mathrm{n}}(\mathrm{n}=1$ or 2$)$ is stirred with $\mathrm{KBHEt}_{3}$ for more than $15 \mathrm{~h}$.

9. Vela J, Vaddadi S, Cundari TR, Smith JM, Gregory EA, Lachicotte RJ, Flaschenriem CJ, Holland PL. Organometallics 2004;23:5226-5239.

13. Mehn MP, Brown SD, Paine TK, Brennessel WW, Cramer CJ, Peters JC, Que L Jr. Dalton 2006:13471351.

14. Examples of stoichiometric B-C bond cleavage by transition metals: (a) Sacconi L, Dapporto P, Stoppioni P. Inorg Chem 1976;15:325-329. (b) Siegmann K, Pregosin PS, Venanzi LM. Organometallics 1989;8:2659-2664. (c) Thaler EG, Caulton KG. Organometallics 1990;9:18711876. (d) Aresta M, Quaranta E, Tommasi I, Derien S, Dunach E. Organometallics 1995;14:3349_ 3356. (e) Spence RE, Piers WE, Sun Y, Parvez M, MacGillivray LR, Zaworotko MJ. Organometallics 1998;17:2459-2469. (f) Lee LWM, Piers WE, Elsegood MRJ, Clegg W, Parvez M. Organometallics 1999;18:2947-2949. (g) Pleènik CE, Liu FC, Liu S, Liu J, Meyers EA, Shore SG. Organometallics 2001;20:3599-3606. (h) Schebler PJ, Mandimutsira BS, Riordan CG, Liable-Sands LM, Incarvito 
CD, Rheingold AL. J Am Chem Soc 2001;123:331-332. [PubMed: 11456520] (i) Hayes PG, Piers WE, Parvez M. Organometallics 2005;24:1173-1183.

15. (a) Marks TJ, Kolb JR. Chem Rev 1977;77:263-93. (b) Ghilardi CA, Innocenti P, Midollini S, Orlandini A. J Organomet Chem 1982;231:C78-C80. (c) Ghilardi CA, Innocenti P, Midollini S, Orlandini A. J Chem Soc, Dalton Trans 1985:605-9. (d) Jia G, Lough AJ, Morris RH. J Organomet Chem 1993;461:147-56.

16. Kandiah M, McGrady GS, Decken A, Sirsch P. Inorg Chem 2005;44:8650-8652. [PubMed: 16296816]

17. (a) Liu FC, Plecnik CE, Liu S, Liu J, Meyers EA, Shore SG. J Organomet Chem 2001;627:109-120. (b) Liu FC, Chen JH, Chen SC, Chen KY, Lee GH, Peng SM. J Organomet Chem 2005;690:291300 .

18. (a) Fryzuk MD, Lloyd BR, Clentsmith GKB, Rettig SJ. J Am Chem Soc 1994;116:3804-3812. (b) Galler JL, Goodchild S, Gould J, McDonald R, Sella A. Polyhedron 2004;23:253-262. (c) Crestani MG, Munoz-Hernandez M, Arevalo A, Acosta-Ramirez A, García JJ. J Am Chem Soc 2005;127:18066-18073. [PubMed: 16366558]

19. Selected examples of hydridoborate complexes formed from transition metal hydride complexes: (a) Baker RT, Ovenall DW, Harlow RL, Westcott SA, Taylor NJ, Marder TB. Organometallics 1990;9:3028-3030. (b) Baker RT, Calabrese JC, Westcott SA, Marder TB. J Am Chem Soc 1995;117:8777-8784. (c) Essalah K, Barthelat JC, Montiel V, Lachaize S, Donnadieu B, Chaudret B, Sabo-Etienne S. J Organomet Chem 2003;680:182-187. (d) Westcott SA, Marder TB, Baker RT, Harlow RL, Calabrese JC, Lam KC, Lin Z. Polyhedron 2004;23:2665-2677.

20. Activation parameters derived from experiments without $\mathrm{Hg}^{0}$ gave similar values of $\Delta \mathrm{H}^{*}=21.6 \pm$ $0.7 \mathrm{kcal} / \mathrm{mol}$ and $\Delta \mathrm{S}^{\dagger}=2.3 \pm 0.6 \mathrm{eu}$. This suggests that the reaction profile is the same in the presence of $\mathrm{Hg}^{0}$.

21. Nath J, Tripathi AD. J Chem Soc, Faraday Trans 1984:1517-1524.

22. Laurence C, Nicolet P, Dalati MT, Abboud JM, Notario R. J Phys Chem 1994;98:5807-5816.

23. Szulejko JE, Mcmahon TB. J Am Chem Soc 1993;115:7839-7848.

24. (a) Thompson ME, Baxter SM, Bulls AR, Burger BJ, Nolan MC, Santarsiero BD, Schaefer WP, Bercaw JE. J Am Chem Soc 1987;109:203-19. (b) Cundari TR. J Am Chem Soc 1994;116:340-7.

25. Hartwig JF, Bhandari S, Rablen PR. J Am Chem Soc 1994;116:1839-1844.

26. Smith G, Cole-Hamilton DJ, Thornton-Pett M, Hursthouse MB. J Chem Soc, Dalton Trans 1983:2501.

27. Brown HC, Krishnamurthy S, Hubbard JL. J Am Chem Soc 1978;100:3343-3349.

28. Wilkins, RG. Kinetics and Mechanism of Reactions of Transition Metal Complexes. VCH; New York: 1991.

29. $\mathrm{L}^{\mathrm{tBu}} \mathrm{Fe}\left(\mathrm{OEt}_{2}\right)^{+} \mathrm{BAr}^{\mathrm{F}}{ }_{4}^{-}$has been reported: Gregory EA, Lachicotte RJ, Holland PL. Organometallics 2005;24:1803-1805.

30. Sciarone TJJ, Meetsma A, Hessen B, Teuben JH. Chem Commun 2002:1580-1581. The equilibrium between $\mathrm{L}^{\mathrm{Me}} \mathrm{Fe}$ (benzyl) $+\mathrm{B}\left(\mathrm{C}_{6} \mathrm{~F}_{5}\right)_{3}$ and $\mathrm{L}^{\mathrm{Me}} \mathrm{Fe}^{+}\left[\mathrm{BnB}\left(\mathrm{C}_{6} \mathrm{~F}_{5}\right)_{3}\right]^{-}$lies to the right

31. This parameter is 1 for trigonal bipyramidal, and 0 for square pyramidal. Addison AW, Rao TN, Reedijk J, Van Rijn J, Verschoor GC. J Chem Soc, Dalton Trans 1984:1349-1356.

32. In the literature, the number of observed N-H stretching vibrations in $\mathrm{Fe}-\mathrm{N}_{2} \mathrm{H}_{4}$ species varies from two to five. (a) Sellmann D, Kreutzer P, Huttner G, Frank A. Z Naturforsch, B: Chem Sci 1978;33B: 1341-1346. (b) Casey MT, Guinan P, Canavan A, McCann M, Cardin C, Kelly NB. Polyhedron 1991;10:483-489. (c) Sellmann D, Soglowek W, Knoch F, Ritter G, Dengler J. Inorg Chem 1992;31:3711-3717. (d) Sellmann D, Shaban SY, Heinemann FW. Eur J Inorg Chem 2004:45914601.

33. (a) Sellmann D, Blum N, Heinemann FW. Z Naturforsch B 2001;56:581-588. (b) Sellmann D, Friedrich H, Knoch F. Z Naturforsch B 1994;49:660-664. (c) Goedken VL, Peng SM, Molin-Norris JA, Park YA. J Am Chem Soc 1976;98:8391-400. [PubMed: 993530] (d) Rath SP, Olmstead MM, Balch AL. Inorg Chem 2004;43:6357-6365. [PubMed: 15446884]

34. (a) Janik JF, Duesler EN, Paine RT. Inorg Chem 1987;26:4341-4345. (b) Park S, Rheingold AL, Roundhill DM. Organometallics 1991;10:615-623. (c) Alcock NW, Bergamini P, Kemp TJ, Pringle PG, Sostero S, Traverso O. Inorg Chem 1991;30:1594-1598. (d) Kormos BL, Jegier JA, Ewbank PC, Pernisz U, Young VG Jr, Cramer CJ, Gladfelter WL. J Am Chem Soc 2005;127:1493-1503. 
[PubMed: 15686383] (e) Stanciu C, Hino SS, Stender M, Richards AF, Olmstead MM, Power PP. Inorg Chem 2005;44:2774-2780. [PubMed: 15819565]

35. (a) Verma AK, Nazif TN, Achim C, Lee SC. J Am Chem Soc 2000;122:11013-11014. (b) Betley TA, Peters JC. J Am Chem Soc 2004;126:6252-6254. [PubMed: 15149221] (c) Thomas CM, Mankad NP, Peters JC. J Am Chem Soc 2006;128:4956-4957. [PubMed: 16608321]

36. In our refinements, the positional parameters and thermal parameter for each hydrogen atom was constrained with respect to the nitrogen atom. If the occupancy of these hydrogen atoms was set to one-half (to consider the possibility of two disordered NH bridges), the thermal parameters for the hydrogen atoms were plainly smaller than those for the parent nitrogen atom, suggesting that insufficient electron density was being modeled, and that a full $\mathrm{H}$ atom was required in each position.

37. Selected N-N bond cleavage by metal clusters: (a) Coucouvanis D. J Biol Inorg Chem 1996;1:594600. (b) Shan H, Yang Y, James AJ, Sharp PR. Science 1997;275:1460-1462. (c) Verma AK, Lee SC. J Am Chem Soc 1999;121:10838-10839. (d) Seino H, Masumori T, Hidai M, Mizobe Y. Organometallics 2003;22:3424-3431. (e) Nakajima Y, Suzuki H. Organometallics 2003;22:959_ 969. (f) Nakajima Y, Inagaki A, Suzuki H. Organometallics 2004;23:4040-4046. (g) Takei I, Dohki K, Kobayashi K, Suzuki T, Hidai M. Inorg Chem 2005;44:3768-3770. [PubMed: 15907098]

38. N-N bond cleavage by mononuclear complexes: (a) Schrock RR, Glassman TE, Vale MG, Kol M. J Am Chem Soc 1993;115:1760-1772. (b) Vale MG, Schrock RR. Inorg Chem 1993;32:2767-2772. (c) Ohki Y, Takikawa Y, Hatanaka T, Tatsumi K. Organometallics 2006;25:3111-3113.By dinuclear complexes: (d) Schollhammer P, Petillon FY, Poder-Guillou S, Saillard JY, Talarmin J, Muir KW. Chem Commun 1996:2633-2634. (e) Schollhammer P, Guenin E, Petillon FY, Talarmin J, Muir KW, Yufit DS. Organometallics 1998;17:1922-1924. (f) Petillon FY, Schollhammer P, Talarmin J, Muir KW. Inorganic Chemistry 1999;38:1954-1955. [PubMed: 11670971] (g) Lin CJ, Hwang WS, Chiang MY. J Organomet Chem 2001;640:85-92. (g) Shaver MP, Fryzuk MD. J Am Chem Soc 2005;127:500-501. [PubMed: 15643855]

39. Eckert NA, Smith JM, Lachicotte RJ, Holland PL. Inorg Chem 2004;43:3306-3321. [PubMed: 15132641]Smith JM, Lachicotte RJ, Holland PL. J Am Chem Soc 2003;125:15752-15753. [PubMed: 14677959]Vela J, Smith JM, Yu Y, Ketterer NA, Flaschenriem CJ, Lachicotte RJ, Holland PL. J Am Chem Soc 2005;127:7857-7870. [PubMed: 15913376] 

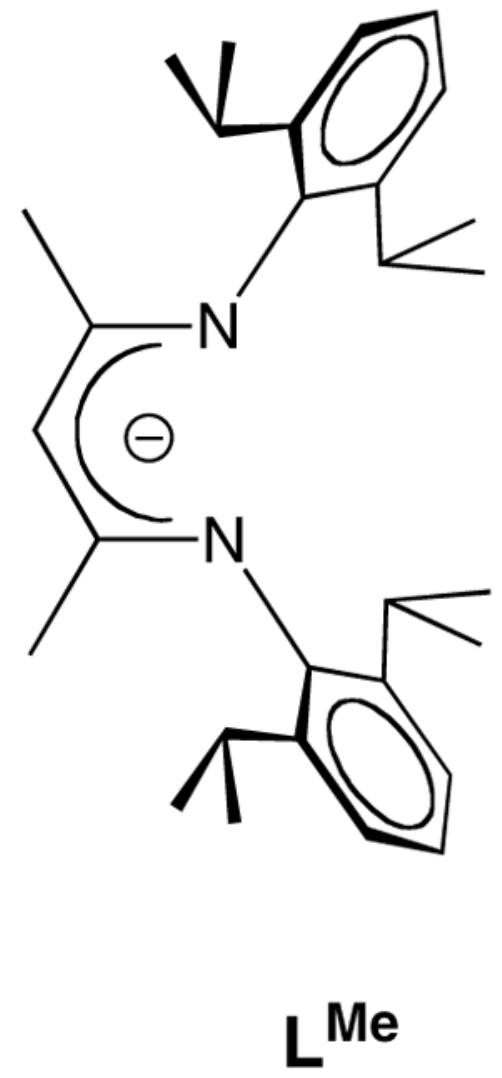

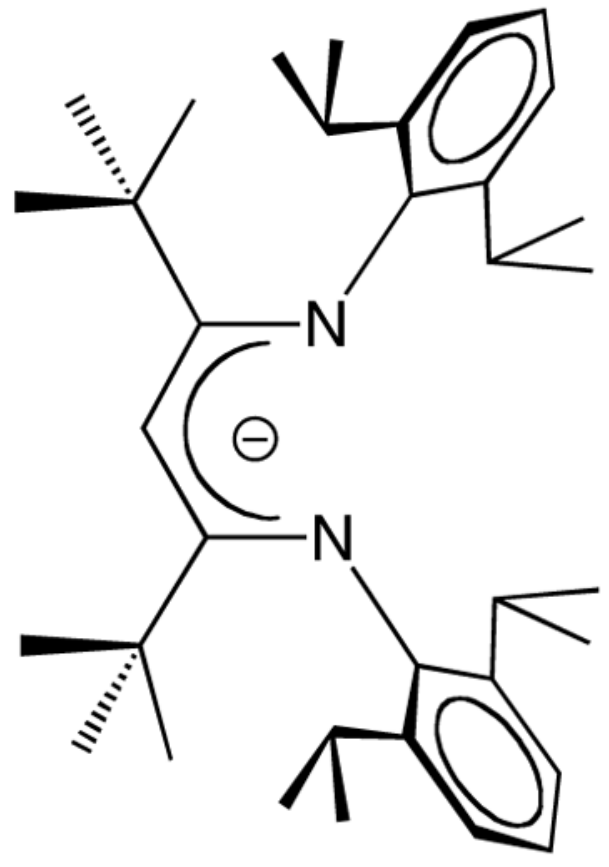

$\mathrm{L}^{\mathrm{tBu}}$

Figure 1.

Diketiminate ligands $\mathrm{L}^{\mathrm{R}}$, where $\mathrm{R}$ indicates the substituent on the $\mathrm{N}_{2} \mathrm{C}_{3}$ backbone. 


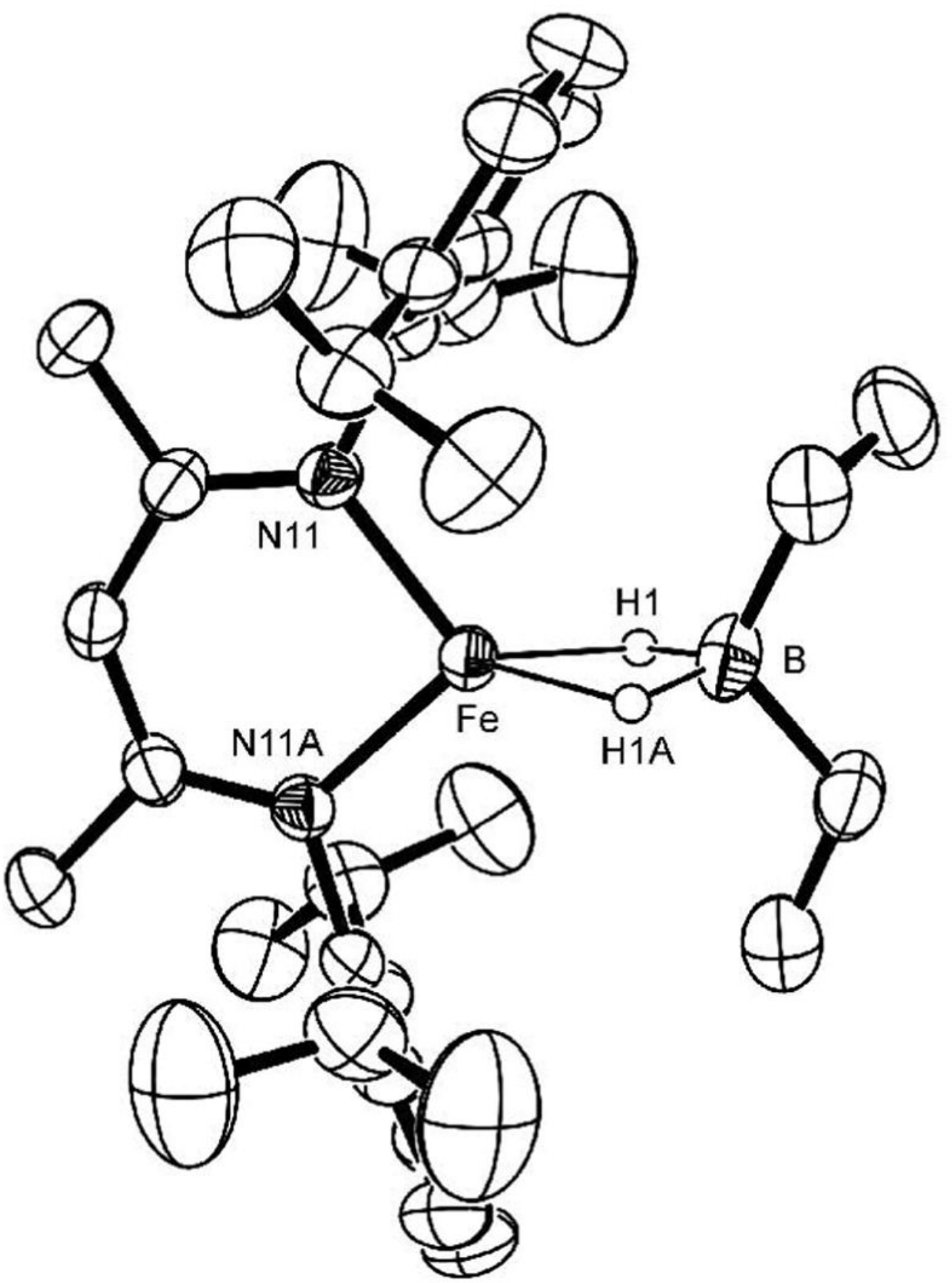

Figure 2.

Thermal-ellipsoid plot of the molecular structure of $\mathrm{L}^{\mathrm{Me}} \mathrm{Fe}(\mu-\mathrm{H})_{2} \mathrm{BEt}_{2}$ (2a). A crystallographic $\mathrm{C}_{2}$ axis passes through $\mathrm{Fe}$ and $\mathrm{B}$. Other crystallographic data are in the Supporting Information. 


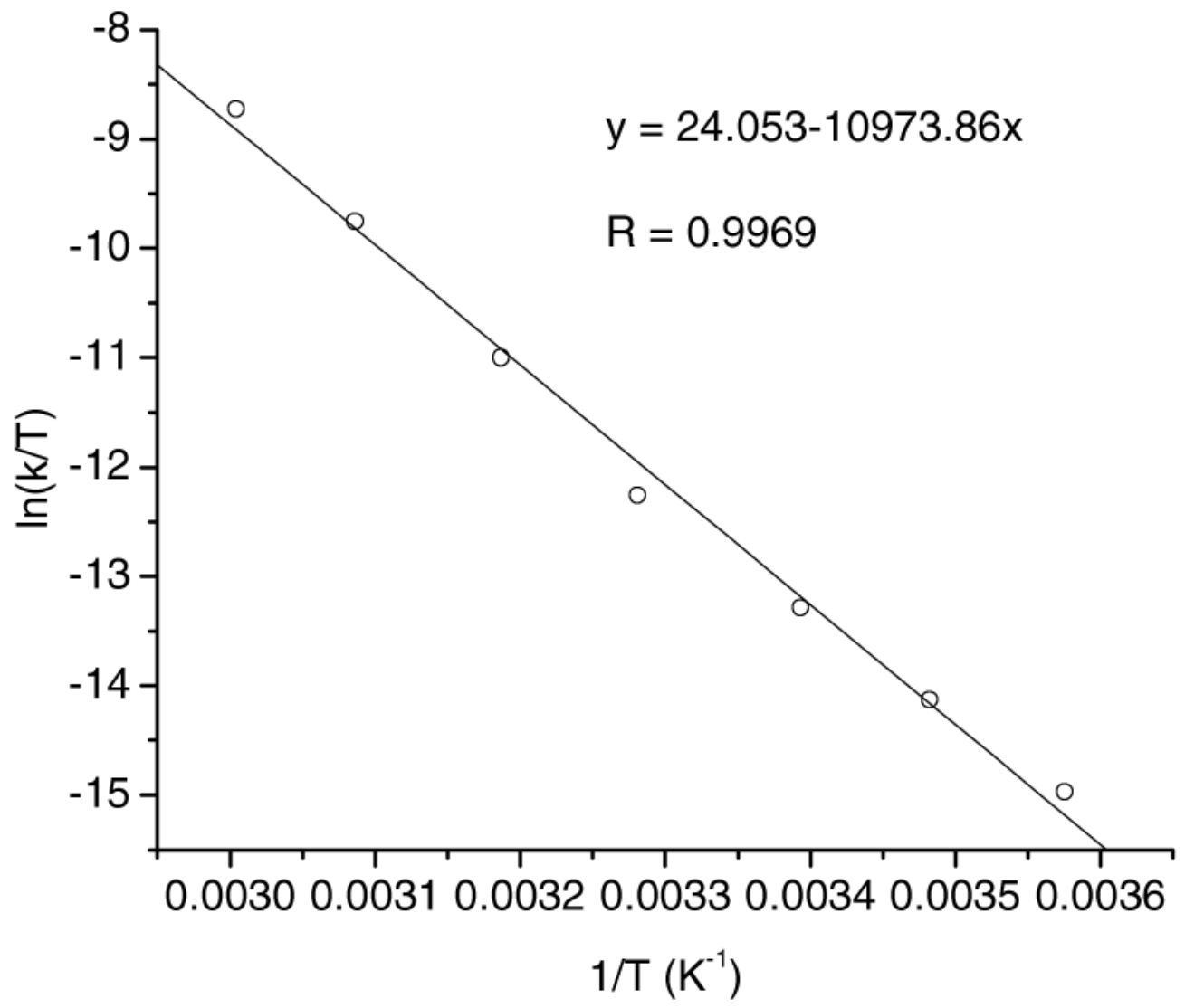

Figure 3.

Eyring plot for the reaction of $\mathbf{1 a}+\mathrm{BEt}_{3}$ to give $\mathbf{2} \mathbf{a}$ and $\mathbf{3 a}$. 


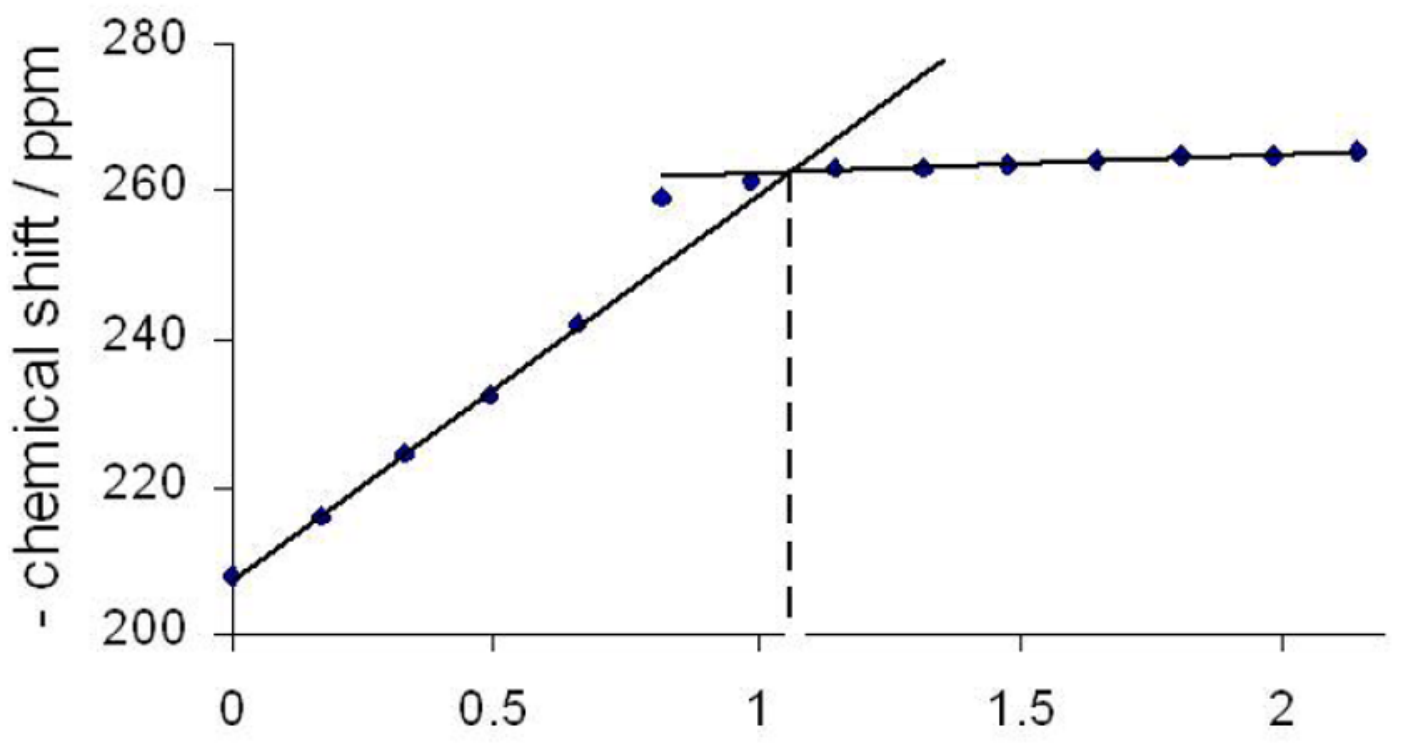

$\mathrm{NH}_{2} \mathrm{NH}_{2}: \mathrm{L}^{\mathrm{Me}} \mathrm{Fe}(\mu-\mathrm{H})_{2} \mathrm{BEt}_{2}$ ratio

Figure 4.

Titration curve and Job plot, using the chemical shift of the ${ }^{1} \mathrm{H}$ NMR resonance near -260 ppm. 


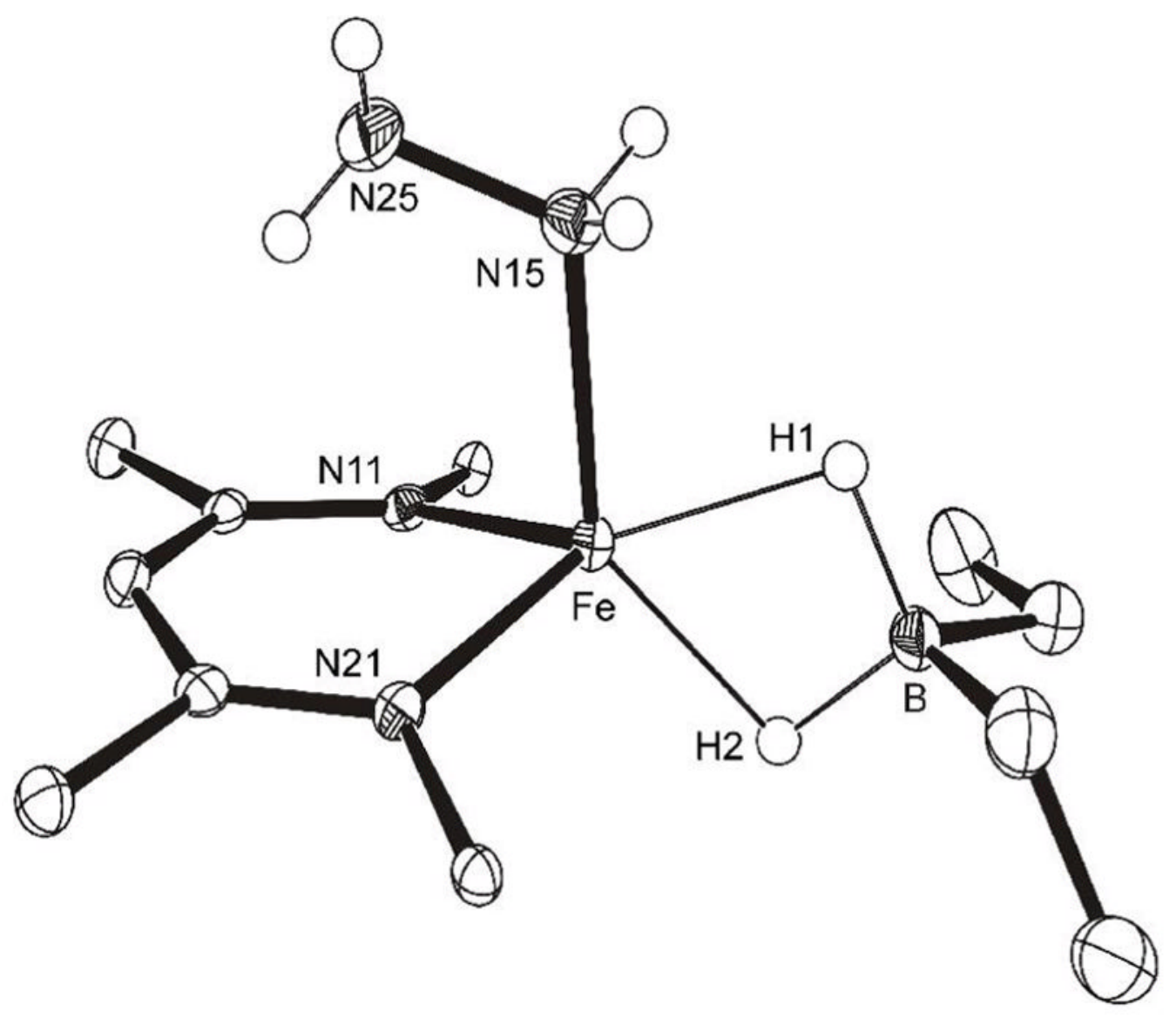

Figure 5.

ORTEP diagram of the molecular structure of $\mathrm{L}^{\mathrm{Me}} \mathrm{Fe}\left(\eta^{1}-\mathrm{H}_{2} \mathrm{NNH}_{2}\right)(\mu-\mathrm{H})_{2} \mathrm{BEt}_{2}$ (4). Aryl groups and $\mathrm{C}-\mathrm{H}$ are omitted for clarity. Important bond distances $(\AA)$ and angles $\left(^{\circ}\right)$ : Fe-H1 1.91(2), $\mathrm{Fe}-\mathrm{H} 2$ 1.82(2), Fe-N15 2.214(2), B-H1 1.22(2), B-H2 1.22(2), N15-N25 1.441(2), Fe-B 2.350(2), H1-Fe-H2 61.2(9), H1-B-H2 103(1). 


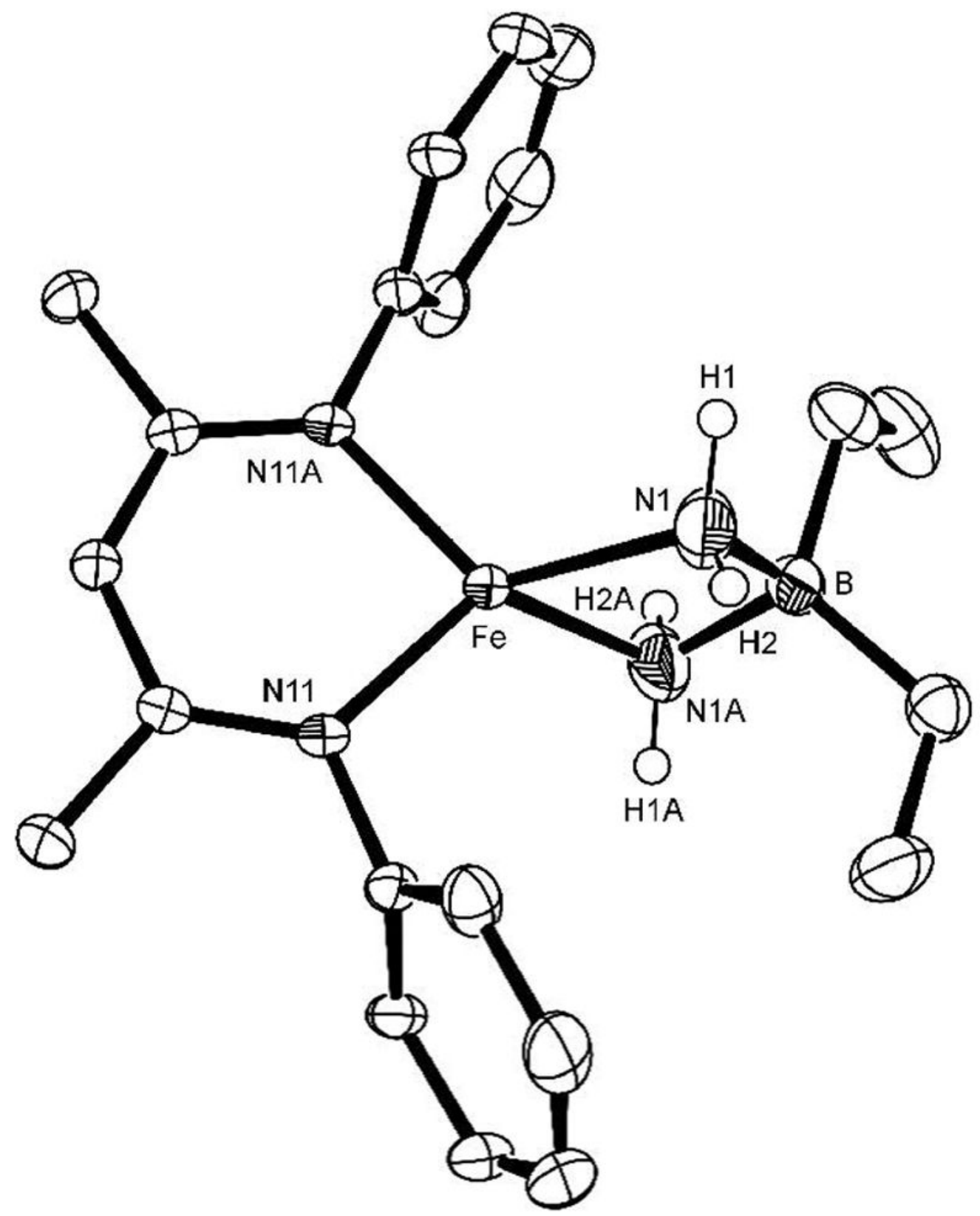

Figure 6.

ORTEP diagram of the molecular structure of $\mathrm{L}^{\mathrm{Me}} \mathrm{Fe}\left(\mu-\mathrm{NH}_{2}\right)_{2} \mathrm{BEt}_{2}(\mathbf{5})$ (aryl isopropyl groups and hydrogens are omitted for clarity). There is a crystallographic $\mathrm{C}_{2}$ axis through $\mathrm{Fe}$ and $\mathrm{B}$. Important bond distances $(\AA)$ and angles $\left({ }^{\circ}\right)$ : Fe-N1 2.064(2), Fe-N1A 2.064(1), B-N1 1.571 (8), B-N1A 1.577(8), N1-N1A: 2.4589(31), N1-Fe-N1A: 73.12(9), N1-B-N1A: 102.5(3). 


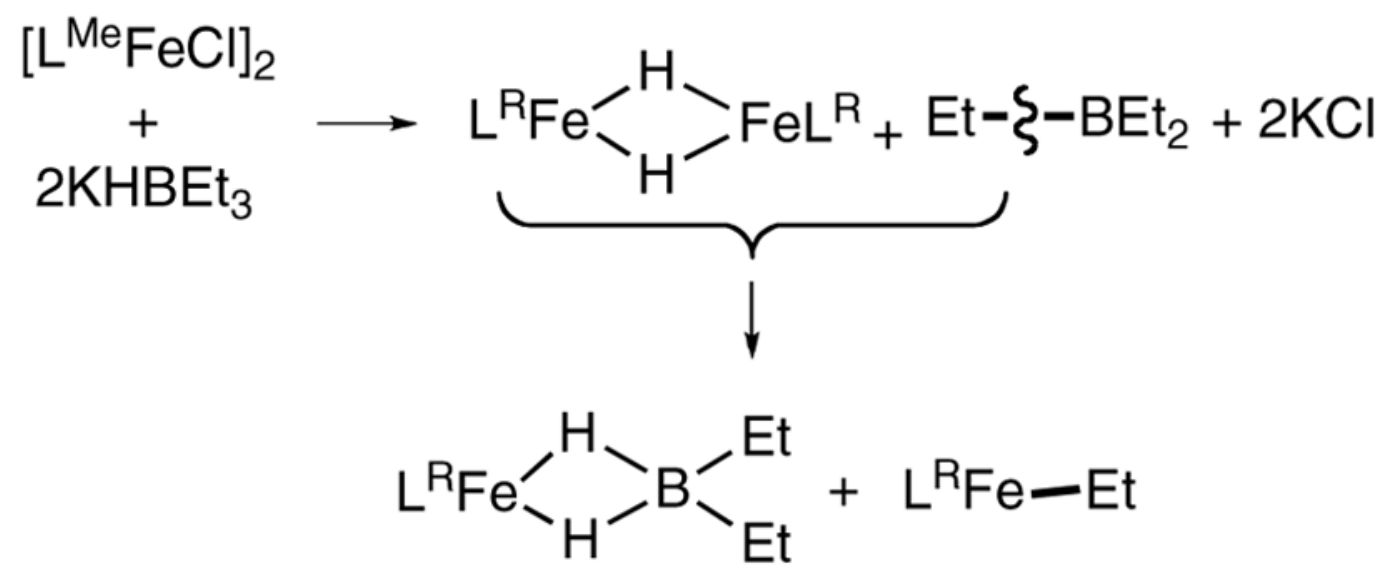

Scheme 1. 

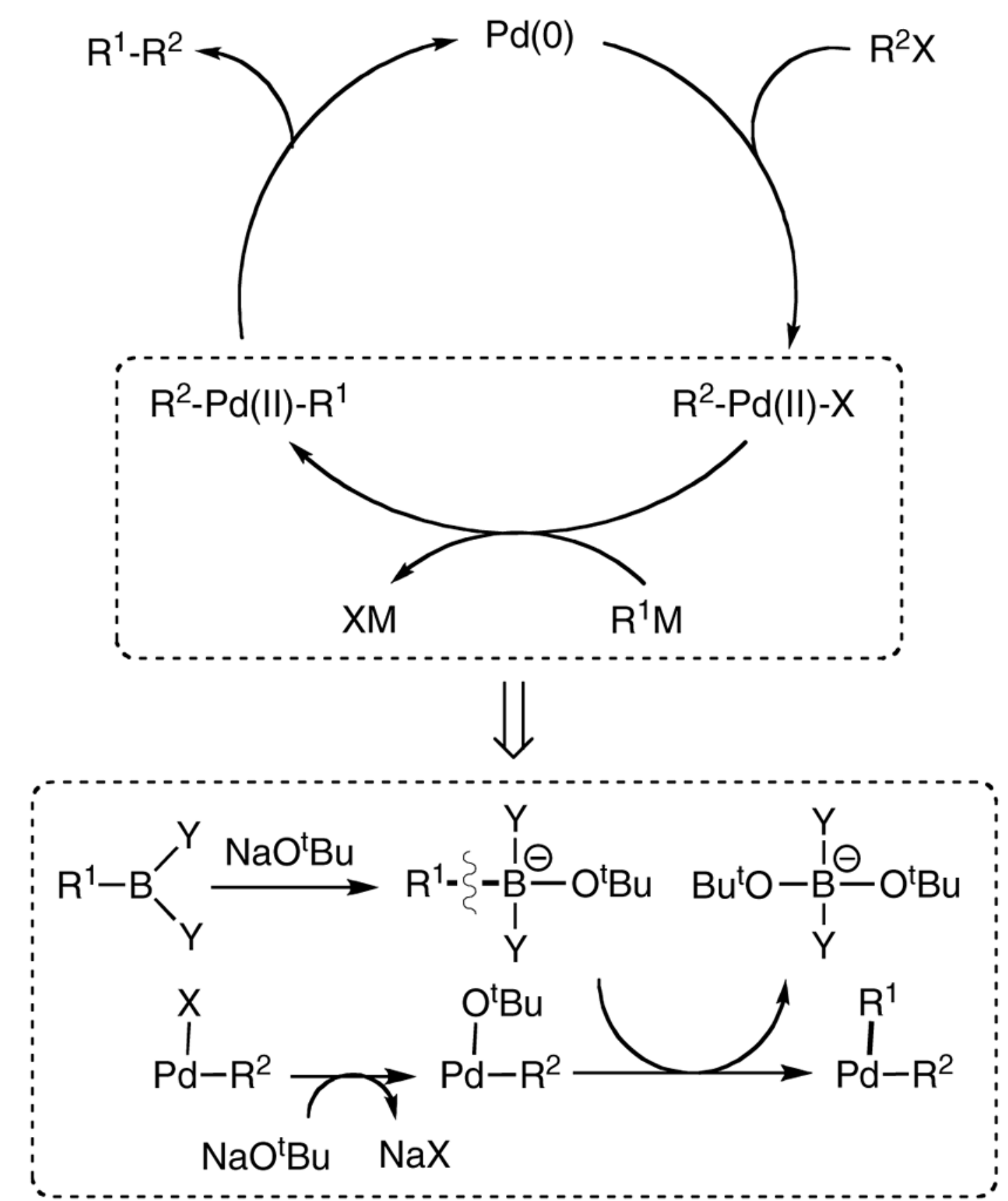

Scheme 2. 


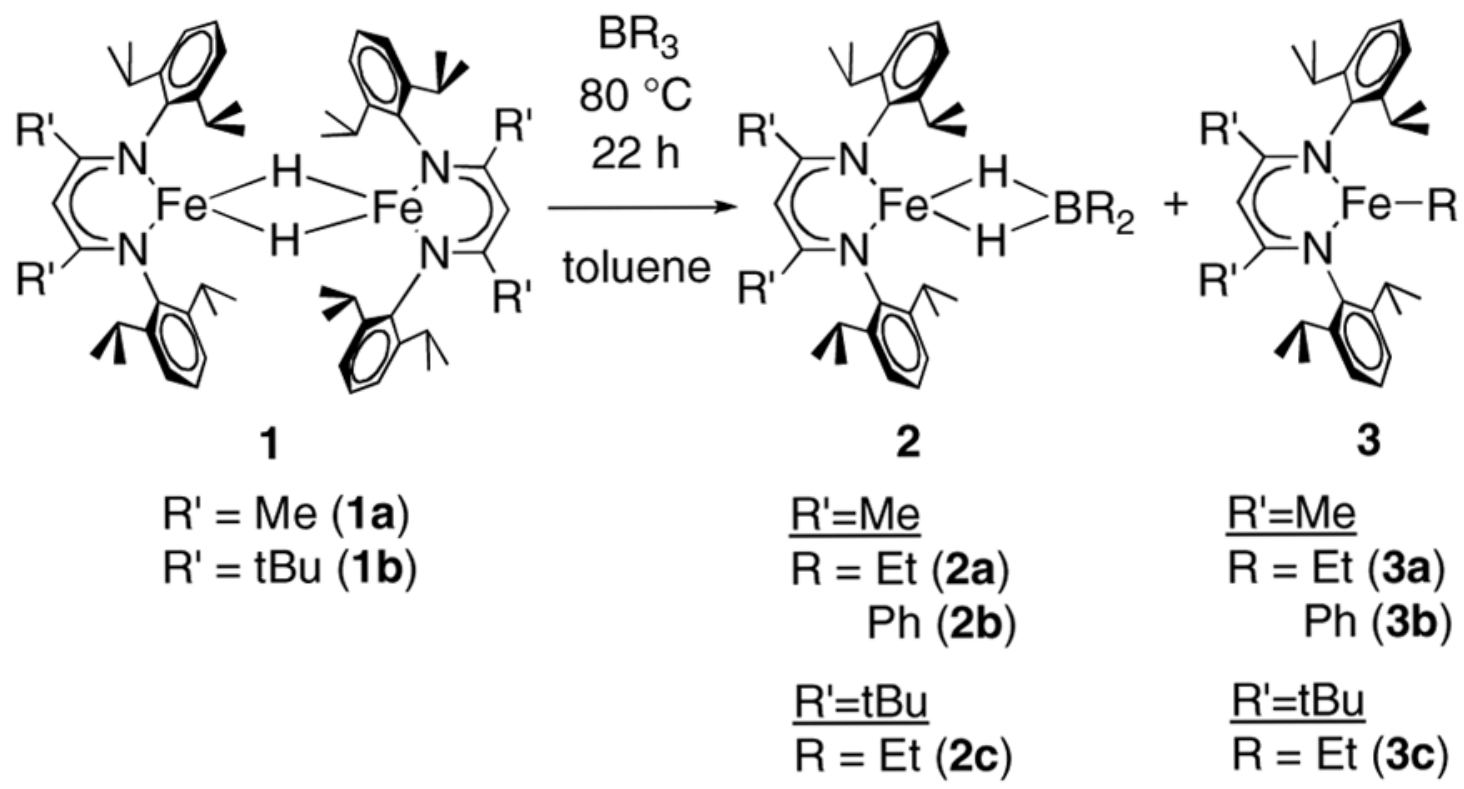

Scheme 3 . 
A

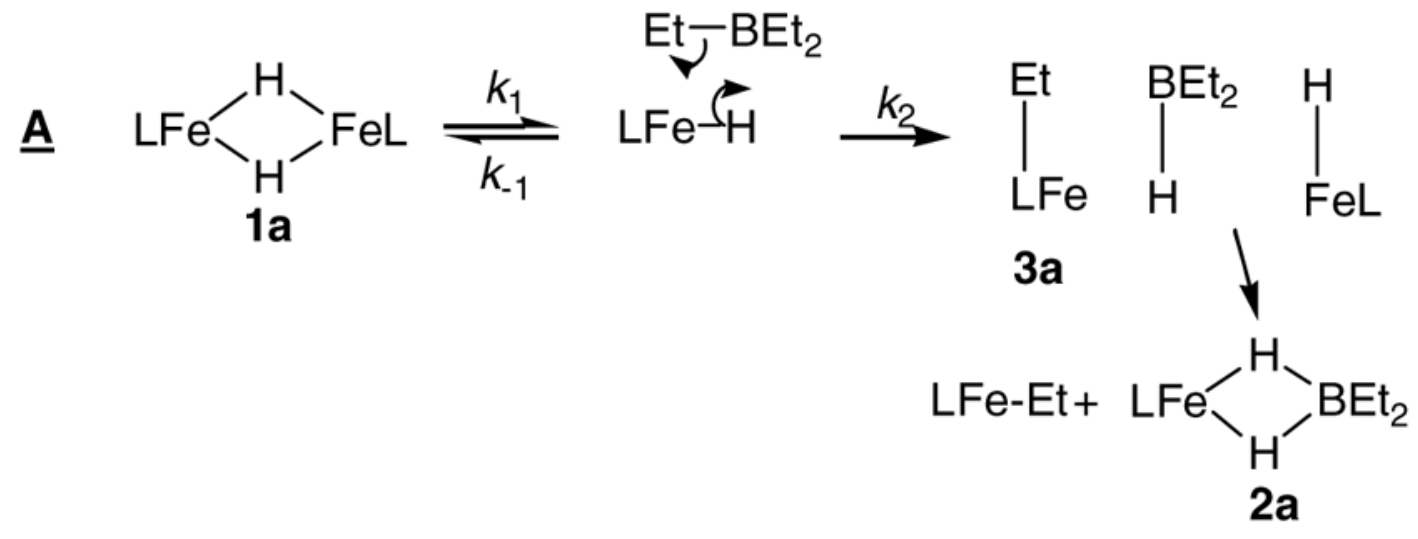

Scheme 4. 


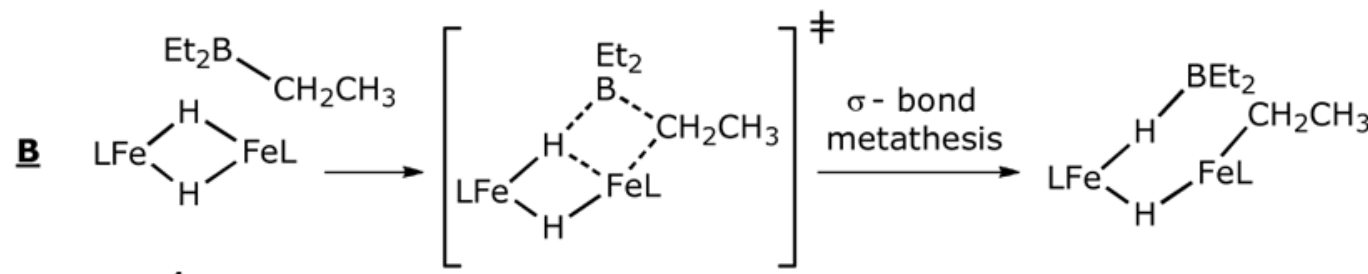
$1 a$

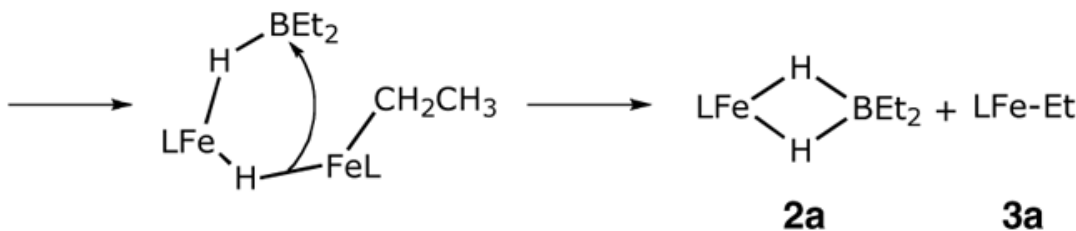

Scheme 5. 


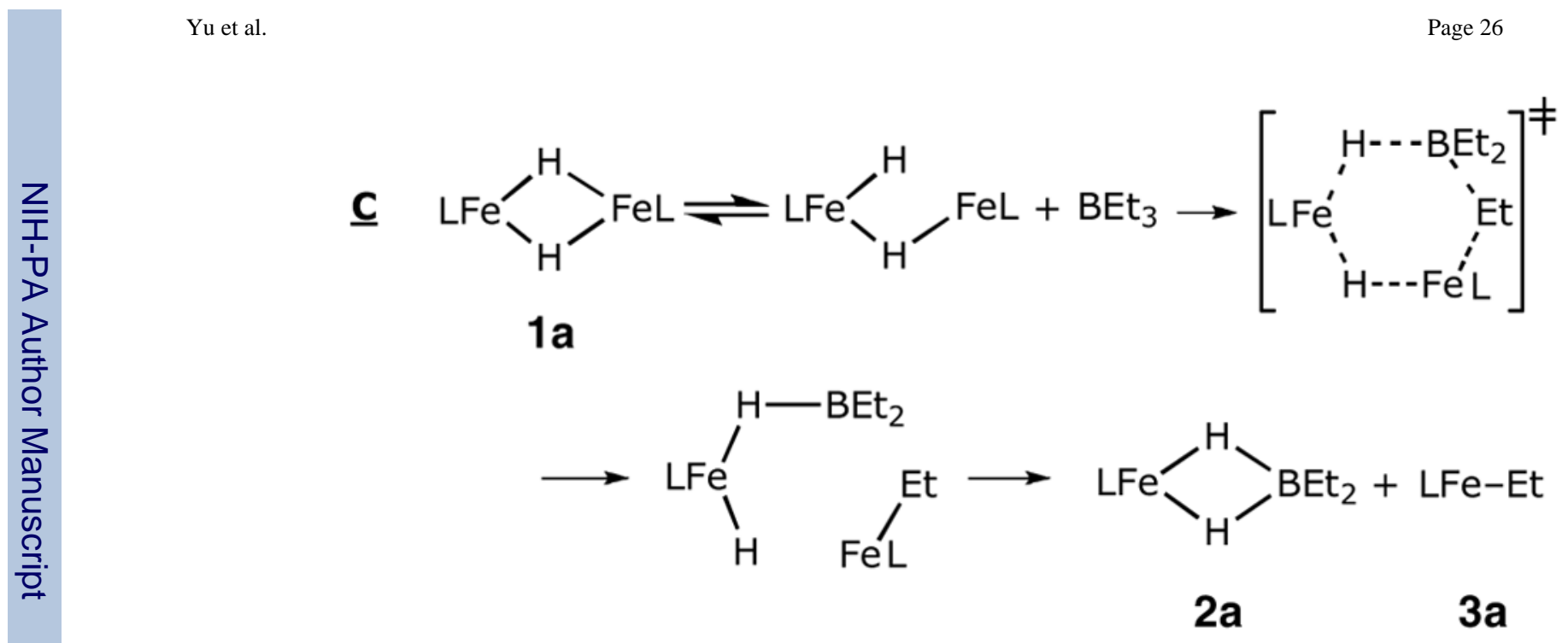

Scheme 6. 


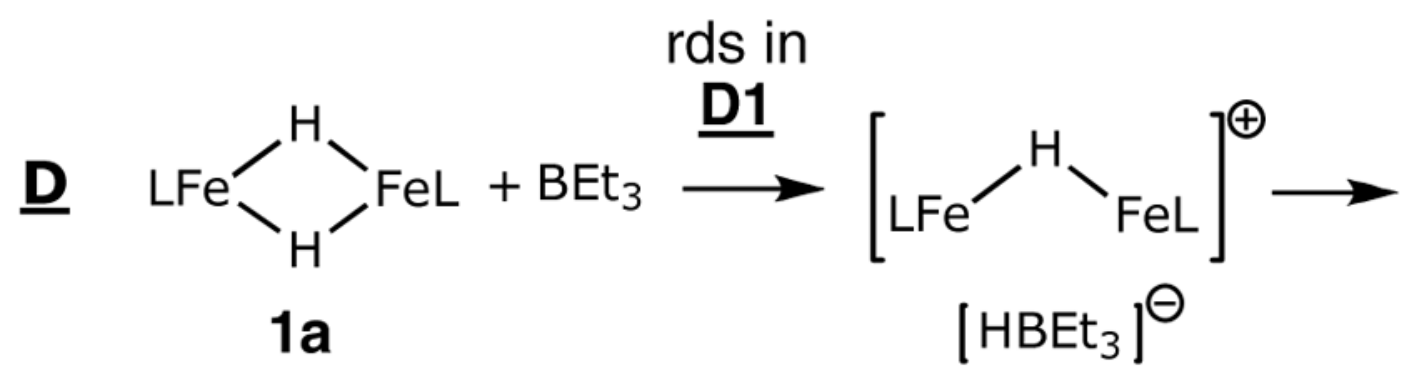

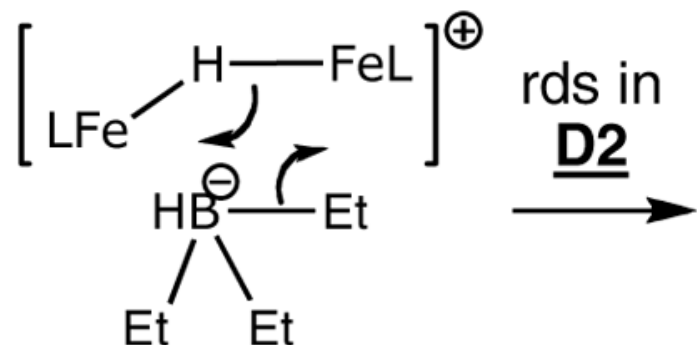<smiles>CC[Te]C1[CH-]C1(F)F</smiles>

Scheme 7. 
E $\quad \mathrm{LFe}_{\mathrm{H}}<\mathrm{H} \backslash \mathrm{FeL} \frac{k_{1}}{k_{-1}} 2 \mathrm{LFe}-\mathrm{H}+2 \mathrm{BEt}_{3}$

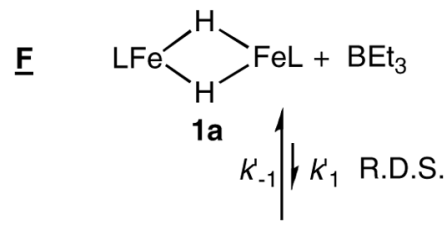

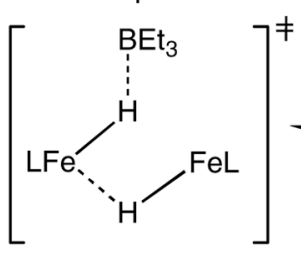

]$^{\neq} \quad k_{2}$

$\mathrm{BEt}_{3}$ $\stackrel{\oplus}{\mathrm{BeE}} \stackrel{\ominus}{\ominus}$

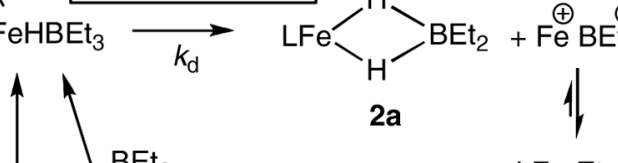

$\mathrm{LFe}-\mathrm{Et}+\mathrm{BEt}_{3}$

$\mathbf{a}^{*}$

$k_{-2}^{\prime} \mathrm{LFeHBEt}_{3}+\mathrm{LFeH}$

$1 / 2[\mathrm{LFeCl}]_{2}+\mathrm{KHBEt}_{3}$

Scheme 8.

Organometallics. Author manuscript; available in PMC 2008 August 21. 


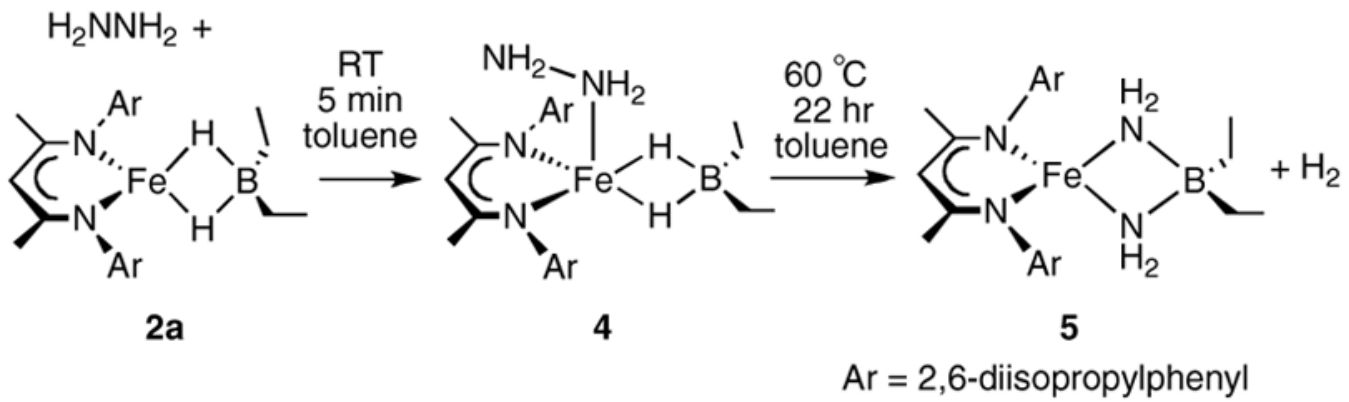

Scheme 9. 


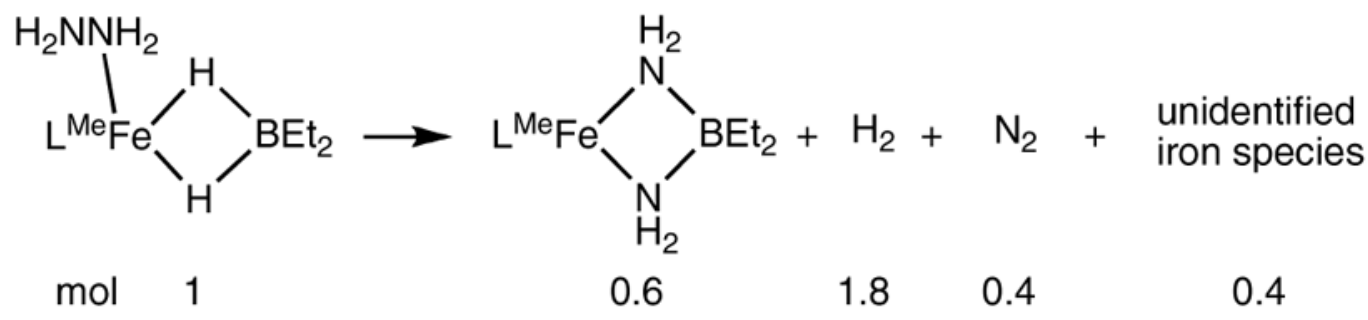

Scheme 10. 
Table 1

Important bond distances and angles for dihydridoborate complexes in this work.

\begin{tabular}{|l|l|l|r|}
\hline Complex & $\mathbf{F e}-\mathbf{H} / \mathbf{\AA}$ & $\mathbf{B}-\mathbf{H} / \AA$ & $\mathbf{F e}$ \\
\hline $\mathrm{L}^{\mathrm{Me}} \mathrm{Fe}(\mu-\mathrm{H} /)_{2} \mathrm{BEt}_{2}$ (2a) & $1.74(2)$ & $1.35(2)$ & $2.237(3)$ \\
\hline $\mathrm{L}^{\mathrm{Me}} \mathrm{Fe}(\mu-\mathrm{H})_{2} \mathrm{BPh}_{2}$ (2b) & $1.72(2), 1.72(2)$ & $1.28(2), 1.19(2)$ & $2.239(2)$ \\
\hline $\mathrm{L}^{\mathrm{Bu}} \mathrm{Fe}(\mu-\mathrm{H})_{2} \mathrm{BEt}_{2}(\mathbf{2 c})$ & $1.74(2), 1.73(2)$ & $1.26(2), 1.21(2)$ & $2.232(1)$ \\
\hline
\end{tabular}


Table 2

Effect of $\left[\mathrm{BEt}_{3}\right]$ on observed rate constant

\begin{tabular}{cccc}
\hline Entry & \multicolumn{2}{c}{ Initial concentrations $(\mathbf{m M})$} & Observed rate constant $\boldsymbol{k}_{\text {obs }}\left(\mathbf{s}^{\mathbf{- 1}}\right)$ \\
\cline { 2 - 3 } & $\mathbf{1}$ & $\mathbf{B E t}_{\mathbf{3}}$ & \\
\cline { 2 - 4 } 1 & 6.4 & 64.8 & $2.2(4) \times 10^{-3}$ \\
2 & 6.4 & 129.6 & $4.7(2) \times 10^{-3}$ \\
3 & 6.4 & 259.0 & $9.4(2) \times 10^{-3}$ \\
\hline
\end{tabular}




\section{Table 3}

Effect of [1a] on observed rate constant ${ }^{a}$

\begin{tabular}{cccc}
\hline Entry & \multicolumn{2}{c}{ Initial concentrations $(\mathbf{m M})$} & \multicolumn{1}{c}{${\text { Observed rate constant } \boldsymbol{k}_{\text {obs }}\left(\mathbf{s}^{-\mathbf{1}}\right)}$} \\
\cline { 2 - 4 } & $\mathbf{1 a}$ & $\mathbf{B E t}_{\mathbf{3}}$ & \\
\hline 1 & 11.6 & 418.8 & $6.58(4) \times 10^{-3}$ \\
2 & 20.8 & 418.8 & $4.59(2) \times 10^{-3}$ \\
3 & 30.8 & 418.8 & $4.52(4) \times 10^{-3}$ \\
4 & 41.6 & 418.8 & $4.27(8) \times 10^{-3}$ \\
\hline
\end{tabular}

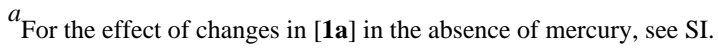


Table 4

Rate constants with variation of $\mathrm{R}$ groups on the diketiminate and borane ${ }^{a}$

\begin{tabular}{|r|c|c|}
\hline Iron hydride reagent & $\mathbf{B R}_{\mathbf{3}}$ reagent & Pseudo first-order rate constant $\boldsymbol{k}_{\mathbf{\text { obs }}} \mathbf{s}^{-\mathbf{s}}$ \\
\hline $\mathrm{L}^{\mathrm{Me}} \mathrm{Fe}(\mu-\mathrm{H})_{2} \mathrm{FeL}^{\mathrm{Me}}(\mathbf{1 a})$ & $\mathrm{BEt}_{3}$ & $3.09(2) \times 10^{-3}$ \\
\hline $\mathrm{L}^{\mathrm{Me}} \mathrm{Fe}(\mu-\mathrm{H})_{2} \mathrm{FeL}^{\mathrm{Me}}(\mathbf{1 a})$ & $\mathrm{BPh}_{3}$ & $8.91(5) \times 10^{-3}$ \\
\hline $\mathrm{L}^{\mathrm{tBu}} \mathrm{Fe}(\mu-\mathrm{H})_{2} \mathrm{FeL}^{\mathrm{L}}{ }^{\mathrm{Iu}}(\mathbf{1 b})$ & $\mathrm{BEt}_{3}$ & $4.8(2) \times 10^{-3}$ \\
\hline
\end{tabular}

$a_{[\mathrm{BR} 3]}=0.419 \mathrm{M},\left[\mathrm{L}^{\mathrm{R}} \mathrm{Fe}(\mu-\mathrm{H})_{2} \mathrm{FeL}^{\mathrm{R}}\right]=26 \mathrm{mM}, \mathrm{T}=40^{\circ} \mathrm{C}$. 


\section{Table 5}

Solvent effect on rate constant ${ }^{a}$ Solvent

$\mathrm{C}_{6} \mathrm{D}_{6}$

THF-d 8

$75 \% o-\mathrm{C}_{6} \mathrm{H}_{4} \mathrm{~F}_{2}+25 \% \mathrm{C}_{6} \mathrm{D}_{6}$ $2.25^{21}$

$7.47^{22}$

$11.26^{b}$

$\begin{array}{lll}\text { [BEt }_{\mathbf{3}} \text { ] } & \mathbf{[ 1 a ]} & \mathbf{k}_{\text {obs }}\left(\mathbf{s}^{-\mathbf{1}}\right) \\ 419 \mathrm{mM} & 21.1 \mathrm{mM} & 3.33(1) \times 10^{-3} \\ 419 \mathrm{mM} & 23.2 \mathrm{mM} & 5.77(5) \times 10^{-3} \\ 419 \mathrm{mM} & 24.5 \mathrm{mM} & 2.57(3) \times 10^{-3}\end{array}$

${ }^{a}$ Monitored at $40{ }^{\circ} \mathrm{C}$. These experiments were performed without mercury, and therefore the rate constants differ slightly from those in Table 4 .

${ }^{b}$ The dielectric constant for the mixed solvent is estimated as the weighted average of 14.26 (pure $o-\mathrm{C}_{6} \mathrm{H}_{4} \mathrm{~F}_{2}$ ) ${ }^{23}$ and 2.25 (pure $\mathrm{C}_{6} \mathrm{D}_{6}$ ). 